\title{
Process-based simulation of seasonality and drought stress in monoterpene emission models
}

\author{
R. Grote ${ }^{1}$, T. Keenan ${ }^{2}$, A.-V. Lavoir ${ }^{3}$, and M. Staudt ${ }^{3}$ \\ ${ }^{1}$ Karlsruhe Institute of Technology, Institute for Meteorology and Climate Research (IMK-IFU), Kreuzeckbahnstrasse 19, \\ 82467 Garmisch-Partenkirchen, Germany \\ ${ }^{2}$ CREAF, Autonomous University of Barcelona (UAB), 08139 Bellaterra, Barcelona, Spain \\ ${ }^{3}$ DREAM team, Centre d'Ecologie Fonctionnelle et Evolutive - Centre National pour la Recherche Scientifique \\ UMR 5175 (CEFE-CNRS), 1919 Rte de Mende, 34293 Montpellier Cedex5, France
}

Received: 25 August 2009 - Published in Biogeosciences Discuss.: 11 September 2009

Revised: 29 December 2009 - Accepted: 5 January 2010 - Published: 20 January 2010

\begin{abstract}
Canopy emissions of volatile hydrocarbons such as isoprene and monoterpenes play an important role in air chemistry. They depend on various environmental conditions, are highly species-specific and are expected to be affected by global change. In order to estimate future emissions of these isoprenoids, differently complex models are available. However, seasonal dynamics driven by phenology, enzymatic activity, or drought stress strongly modify annual ecosystem emissions. Although these impacts depend themselves on environmental conditions, they have yet received little attention in mechanistic modelling.

In this paper we propose the application of a mechanistic method for considering the seasonal dynamics of emission potential using the "Seasonal Isoprenoid synthase Model" (Lehning et al., 2001). We test this approach with three different models (GUENTHER, Guenther et al., 1993; NIINEMETS, Niinemets et al., 2002a; BIM2, Grote et al., 2006) that are developed for simulating light-dependent monoterpene emission. We also suggest specific drought stress representations for each model. Additionally, the proposed model developments are compared with the approach realized in the MEGAN (Guenther et al., 2006) emission model. Models are applied to a Mediterranean Holm oak (Quercus ilex) site with measured weather data.

The simulation results demonstrate that the consideration of a dynamic emission potential has a strong effect on annual monoterpene emission estimates. The investigated models, however, show different sensitivities to the procedure for determining this seasonality impact. Considering a drought impact reduced the differences between the applied models and decreased emissions at the investigation site by approxi-
\end{abstract}

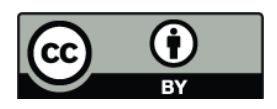

Correspondence to: R. Grote (ruediger.grote@imk.fzk.de) mately $33 \%$ on average over a 10 year period. Although this overall reduction was similar in all models, the sensitivity to weather conditions in specific years was different. We conclude that the proposed implementations of drought stress and internal seasonality strongly reduce estimated emissions and indicate the measurements that are needed to further evaluate the models.

\section{Introduction}

Isoprenoids represent a heterogeneous compound class consisting of a wide range of reactive volatile hydrocarbons (i.e. isoprene, monoterpenes, and sesquiterpenes) which are emitted by most plant species. These emissions are highly important for air chemistry and air pollution (e.g. Fuentes et al., 2000; Kanakidou et al., 2005; Szidat et al., 2006; Gelencser et al., 2007), and are likely to indirectly affect the concentration of greenhouse gases (e.g. Pierce et al., 1998; Olofsson et al., 2005). Air pollution impacts depend on the availability of reaction partners, i.e. reactive nitrogen compounds, which have a regionally specific seasonal pattern that is driven by anthropogenic as well as biological activities (e.g. Pierce et al., 1998; Fiore et al., 2005; Tie et al., 2006). Thus, it is not only the total amount but also the timing of emissions that is important.

Plant physiological processes are largely affected by seasonal cycles of environmental conditions such as temperature, radiation, and water availability. It has been recognized that climate change already affects seasonal cycles in terrestrial ecosystems, most notably in phenology (e.g. Walther et al., 2002; Menzel et al., 2006), and will continue to do so in the future (Gitay et al., 2001). Temperature is expected to increase while water availability will probably decrease in

Published by Copernicus Publications on behalf of the European Geosciences Union. 
many regions, one of them being the Mediterranean basin (Giorgi et al., 2004; Giorgi 2006; Beniston et al., 2007; IPCC, 2007). It is thus expected that temperature is affecting short-term isoprenoid emission directly by enhancing biosynthesis and evaporation, but also indirectly by changing boundary conditions on medium and longer time scales. These are particularly the dynamics of foliage development and enzymatic activities that are related to cumulative temperature (and others) and are known to affect emission (Mayerhofer et al., 2005; Pio et al., 2005). Seasonal changes in emissions due to these two factors are termed as seasonality throughout the following text. Seasonality effects are reported for deciduous as well as coniferous species. Additionally, environmental stresses, which also often follow a seasonal dynamic, such as drought, can alter the physiological pre-conditions for plant emission (Monson et al., 2007; Grote et al., 2009a). A better understanding of these seasonal dynamics is therefore also necessary for reliable projections of both current and projected future isoprenoid emissions.

The short-term emission of isoprenoids is a function of temperature and radiation and has been described as such by several models (see reviews in Arneth et al., 2007; Grote and Niinemets, 2008), which have been applied on local, regional and global scales. These models, however, have a developmental bias towards short term responses - partly due to a lack of long term seasonal measurement data. Other processes, operating over longer time scales, such as the effect of seasonality, the effect of seasonal cycles of water availability, and potential effects of $\mathrm{CO}_{2}$ fertilisation have received little attention. Projected future atmospheric $\mathrm{CO}_{2}$ concentration changes have been suggested to modify the emission response on the decadal or longer time scale (Possell et al., 2005; Arneth et al., 2007, 2008a). The determination of seasonality and drought effects, however, has not as yet been systematically investigated, and still represents a major uncertainty of biogenic emission simulations (Funk et al., 2005; Monson et al., 2007; Arneth et al., 2008b; Keenan et al., 2009c).

The potential (or basal) emission is a species specific factor (hereafter referred to as emission factor (EF)) that describes emission rates under standard conditions (e.g. $30^{\circ} \mathrm{C}$, $1000 \mu \mathrm{mol} \mathrm{PAR} \mathrm{m}^{-2} \mathrm{~s}^{-1}$ ). The isoprenoid emissions from most models scale linearly with this factor which is known to change considerably during the year (e.g. Monson et al., 1994; Hanson and Sharkey, 2001; Hakola et al., 2006; Holzinger et al., 2006). The change in potential emission throughout the year is either neglected (particularly when only short periods are investigated) or empirically derived correction factors/equations are introduced (e.g. Staudt et al., 2000, 2002; Schaab et al., 2003; Keenan et al., 2009c). Although it is known that emission potential depends on prevailing temperature and light conditions (e.g. Staudt et al., 2003), only a few approaches have been developed to derive seasonality dynamically from environmental influences:
Fuentes and Wang (1999) used a function fitted to cumulated temperature or growing degree days, respectively, He et al. (2000) correlated emission potential to the number of monthly sunshine hours, and Geron et al. (2000) applied the integrated temperature of the previous $18 \mathrm{~h}$ instead of instantaneous temperature. However, there are only two models known to the authors that explicitly account for the cumulative effect of both impacts temperature and radiation, throughout longer time periods. One is the respective routine of the MEGAN model (Guenther et al., 2006; Müller et al., 2008), which applies an empirical adjustment based on the past 10 days of light and temperature to calculate emissions, and the other is the SIM model that derives the seasonal course of the isoprenoid forming enzyme activity, which is closely related to potential emission, explicitly from the previous days climatic conditions (Lehning et al., 2001). Only the latter model reflects the finding that seasonal changes in enzyme activity result from physiological production and destruction processes (Lehning et al., 1999; Loreto et al., 2001; Fischbach et al., 2002; Mayrhofer et al., 2005).

The second seasonal emissions driver is drought stress. Mild drought stress does not affect the light dependent emission of isoprene and monoterpenes or reduces it only moderately (e.g. Bertin and Staudt, 1996; Brilli et al., 2007; Staudt et al., 2008). Strong, long-lasting drought, however, decreases isoprenoid emissions considerably (Hansen et al., 1999; Pegoraro et al., 2004, Lavoir et al., 2009). Overall, an impact of summer drought on annual isoprenoid emission has frequently been observed (Geron et al., 1997; Staudt et al., 2002; Plaza et al., 2005). A mechanistic understanding of isoprenoid responses to drought stress, however, has not yet been established. Due to this limited understanding as well as the strong dependence on species and site, drought effects have not yet been consistently represented in emission modelling.

In this paper, we investigate the sensitivity to drought stress and seasonality of three isoprenoid models commonly used in regional/global applications (GUENTHER, Guenther et al., 1993; MEGAN, Guenther et al., 2006; and NIINEMETS, Niinemets et al., 2002a), and one model of higher detail that has only been applied to specific sites and species (BIM2, Grote et al., 2006). We concentrate on the investigation of light-dependent monoterpene emissions, whose emission behaviour is generally similar to that of isoprene (Ciccioli et al., 1997). Emissions from storages are assumed not to be relevant in the investigated ecosystem and are thus not accounted for. The models are compared on the basis of the same canopy model which is constrained through Eddyflux data (Baldocchi et al., 2001; Misson et al., 2007) and the boundary conditions of a Mediterranean Holm oak stand (Quercus ilex). Emissions measurements, gathered on site, are used to calibrate the models.

Based on these boundary conditions, we propose the implementation of the SIM model as the seasonal driver for all emission models except MEGAN, which comes with its own 
seasonality procedure. Additionally, we suggest relations between monoterpene emission and relative soil water availability that are specifically adapted to each of the emission models.

\section{Materials and methods}

\subsection{Site description and data availability}

Data and simulations refer to a study site located $35 \mathrm{~km} \mathrm{NW}$ of Montpellier (Southern France) in the Puéchabon State Forest $\left(3^{\circ} 35^{\prime} 45^{\prime \prime} \mathrm{E}, 43^{\circ} 44^{\prime} 29^{\prime \prime} \mathrm{N}, 270 \mathrm{~m}\right.$ a.s.l.). Vegetation is largely dominated by a dense over-storey of Holm oak (Quercus ilex) trees (mean canopy height: $5.5 \mathrm{~m}$, rooting depth down to $4.5 \mathrm{~m}$ ). The climate is typical Mediterranean with cool and wet winters and warm and dry summers. The mean annual temperature is $13.5^{\circ} \mathrm{C}$ and the mean annual precipitation is $872 \mathrm{~mm}$. Soil texture is homogeneous down to $0.5 \mathrm{~m}$ depth and can be denoted as silty clay loam (referring to the textural triangle, United States Department of Agriculture), with a limestone rock base. For more details on the site see http://www.cefe.cnrs.fr/fe/puechabon/. Eddy covariance fluxes were measured at a half hourly time step at a height of $11 \mathrm{~m}$. The eddy covariance facility included a 3dimensional sonic anemometer (Solent R2 during the 19981999 periods and R3 since 2000, Gill Instruments Instruments, Lymington, UK) and a closed path infrared gas analyzer (IRGA, model LI 6262, Li-Cor Inc.), both sampling at a rate of $21 \mathrm{~Hz}$. Flux data were processed following Aubinet et al. (2000). An overview of the technical facilities can be obtained from the CarboEuroFlux network site at http: //www.bgc-jena.mpg.de/public/carboeur/sites/puechab.html.

Due to the Mediterranean-type climate and the low water holding capacity, the water content in summer falls regularly below the value at which drought stress limitations to photosynthesis are expected (Rambal et al., 2003; Keenan et al., 2009b). The timing and extent of drought conditions varies from year to year, but water content values close to the wilting point are observed almost every year. For the years of measurements, 2005 was slightly cooler (annual average temperature $13.0^{\circ} \mathrm{C}$ ) and 2006 warmer and dryer than the long-term average (total precipitation $773 \mathrm{~mm}$, annual average temperature of $14.1^{\circ} \mathrm{C}$, see Allard et al., 2008). The period 1998 to 2007 that we used to compare the different emission models was slightly warmer and wetter than the long-term average $\left(13.7^{\circ} \mathrm{C}, 913 \mathrm{~mm}\right)$. The standard deviations in this period are $0.6^{\circ} \mathrm{C}$ and $228 \mathrm{~mm}$, respectively.

The investigation of well-watered trees has been carried out at a 10-year old Holm oak plantation which was irrigated regularly during 2006. This plantation is located in Montpellier close to the CEFE-CNRS institute in southern France $\left(43^{\circ} 36^{\prime} \mathrm{N}, 5^{\circ} 53^{\prime} \mathrm{E}\right)$ on a deep clay soil with good water availability. Genetic similarity of the trees to those of the eddy-covariance measurement site is ensured because the trees originate from acorn samples from the same site (Puéchabon State Forest). Since only measurements of new leaves are used for fitting the emission potential of the models, stand structural aspects are not important. Due to the close vicinity of both sites that are only app. $30 \mathrm{~km}$ apart, we assume no difference with respect to their atmospheric climate conditions.

Measurements of leaf scale emissions are taken from Grote et al. (2009a) and Lavoir et al. (2009). They had been conducted from May to October (12 occasions in 2005, 9 occasions in 2006) on the field site Puéchabon at current year leaves of adult trees about every second week under sunlit conditions (mostly between 10 and $12 \mathrm{am}$ ). Three trees per occasion had been sampled. Identical measurements had been carried out in 2006 at the irrigated plot in Montpellier during the weeks in between (9 occasions). All measured leaves ( 3 per occasion) from 2006 had also been used for the enzyme analyses.

Enzyme activity has been determined in 2006 according to standard protocols described in Fischbach et al. (2000) using the same leaves as used for emission measurements. Enzymatic data provide calibration information for the seasonal dynamics model SIM. The emission measurements from the irrigated plot (only 2006) are used to calibrate the combined SIM/ emission models (without drought stress). The emission data from the natural field site (2005 and 2006) are then used to evaluate the results from simulations that included drought stress (= relative soil water depletion). Although drought stress acts differently on the GUENTHER and NIINEMETS models, no model-specific fitting has been carried out. BIM2 relies on previous calibration based on a smaller data set (Grote et al., 2009a). For both years half-hourly weather input data was available. Long term comparisons are based on hourly weather data from 1998 to 2007 . In order to investigate the sensitivity of the models to drought and seasonality, we ran different simulation experiments which considered:

1. a fixed emission factor with no drought stress,

2. a fixed emission factor with drought stress,

3. a seasonally dynamic emission factor with no drought stress and,

4. a seasonally dynamic emission factor including drought stress.

For all long term simulations, the initial set of forest structural boundary conditions was re-set in the model framework at the beginning of each year to avoid confounding effects of shifts in structural components such as leaf area, etc. 


\subsection{Model description}

\subsubsection{Modelling framework}

For all simulations, a modelling framework has been used which is designed to couple one-dimensional biosphere models to describe different processes within the ecosystem. The framework provides climate data and initial variables for every (below- and aboveground) layer of the ecosystem based on initial site information and climate input data. This ensures the same initial conditions and dynamic boundary conditions for all emissions models in the investigation. Shorttimestep model results are aggregated in order to be used as input for models with larger time steps. The models implemented can be applied alternatively or in addition to each other (for more information see Grote, 2007; Grote et al., 2009a, b; Holst et al., 2010).

In the current context the short-term isoprenoid emission models MEGAN (Guenther et al., 2006), GUENTHER (Guenther et al., 1993), NIINEMETS (Niinemets et al., 2002a), and BIM2 (Grote et al., 2006) are coupled with models describing the canopy micro-climate within the canopy (ECM, Grote et al., 2009a) and the soil (DNDC, Li et al., 1992), photosynthesis (FARQUHAR, Farquhar and Von Caemmerer, 1982), phenology (SIM, Lehning et al., 2001; Grote, 2007), and soil hydrological conditions (QUERCUS, Rambal et al., 1993, 2003) (see Fig. 1 and model descriptions below). The seasonal development of enzyme activity and basal emission factors for all emission models but MEGAN are calculated as an addition of the SIM model approach (Lehning et al., 2001), The photosynthesis and emission models are run on a half hourly time step, corresponding to the available weather data. The boundary conditions for emissions, i.e. enzyme activities or basal emission factors, leaf development states, and the state of relative water supply are updated daily.

\subsubsection{Biosphere models}

ECM (empirical canopy model) calculates radiation, temperature, vapour pressure, and wind profiles for a given canopy. The radiation regime is determined using a simple one-dimensional light extinction scheme based on canopy layers with fixed extension and empirical foliage distribution (Grote, 2007). The sunlit and shaded fractions of the foliage are differentiated for each layer (Spitters et al., 1986). Temperature development in the canopy is given by an empirical function for each layer between the canopy upper boundary and at the soil surface. Soil surface temperature is calculated by the DNDC (DeNitrification-DeComposition) module ( $\mathrm{Li}$ et al., 1992) on the basis of heat capacity and conductance of the soil components in each soil layer.

FARQUHAR: The common Farquhar approach (Farquhar and Von Caemmerer, 1982) is used along with the parameterization provided by Long et al. (1991). Stomata conduc-

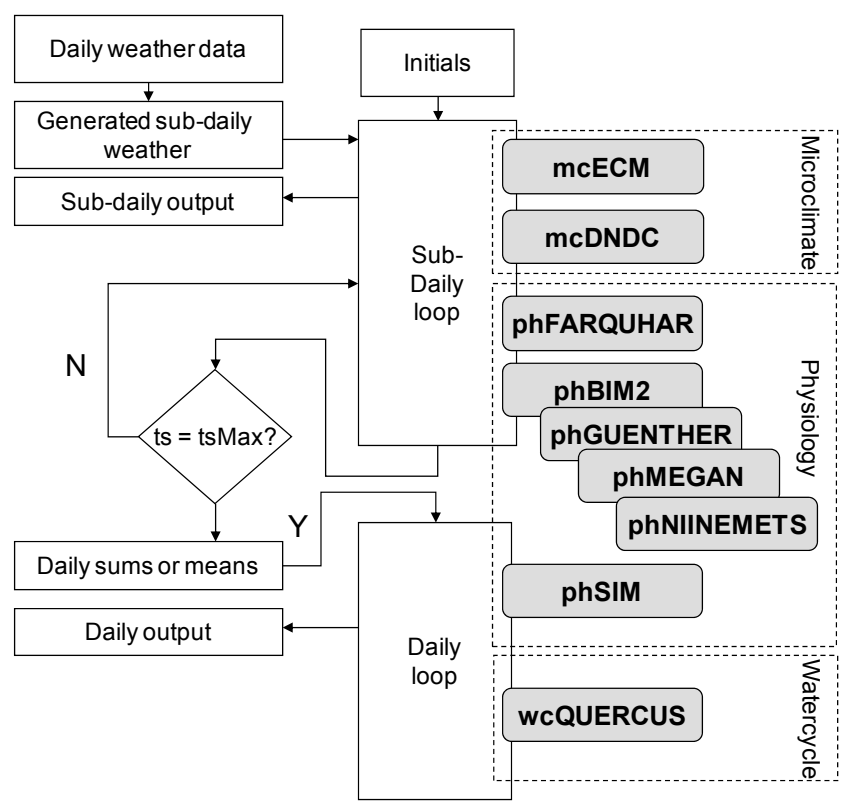

Fig. 1. Model framework. The three modules BIM2, GUENTHER, and NIINEMETS are alternatively called together with the other modules that describe the boundary conditions for isoprenoid emission, i.e. microclimate, physiology (photosynthesis and foliage development), and soil water content. The MEGAN model is in the same module as the GUENTHER model but with additional options to account for the integrated temperature and radiation effects.

tance is calculated with the approach suggested by Ball et al. (1987). Photosynthesis is calculated separately for sunlit and shaded foliage but pooled over each layer for emission input. This is in accordance with the determination of emission activity which is also layer specific.

Drought stress is accounted for by the stomata conductance calculations inherent in the model and additionally by means of a reduction in the rate of electron transport and maximum carboxylation capacity $\left(\mathrm{Vc}_{\max }\right)$ (Keenan et al., 2009b). Here we apply a simple linear relation to relative soil water content (RWC), parameterised from measurements of stomata conductance (Rambal et al., 2003):

$\mathrm{DS}=\min \left(1.0, \frac{\mathrm{RWC}}{\mathrm{RWC}_{\mathrm{lim}}}\right)$

with DS denoting the drought stress scaling factor. The limit value of relative soil water content at which drought stress starts to effect a process $\left(\mathrm{RWC}_{\mathrm{lim}}\right)$ has been set to 0.7 (Rambal et al., 2003; Keenan et al., 2009b).

QUERCUS (Rambal et al., 1993, 2003) uses a lumped approach on soil water conditions considering the whole soil as one layer. Water exceeding the infiltration capacity of the soil is treated as deep drainage that is released over time using an empirical exponential equation. Potential evapotranspiration is estimated with a modified Priestley-Taylor approach (Priestley and Taylor, 1972; with parameter alpha 
fixed to a value of 1.1) that accounts for a variable proportion of ground heat flux in dependence on leaf area index (LAI) and vegetation density. Transpiration is determined from potential evapotranspiration and foliage conductance in half hourly time steps using air temperature and solar irradiation as input. The model has already accurately represented the soil water content throughout the years 1993 to 2006 at the Puéchabon site (see Grote et al., 2009a).

\subsubsection{Emission models}

Three commonly used emission models of varying complexity were coupled to the biosphere modelling framework.

GUENTHER/MEGAN: By far the most widely used model for simulation of natural isoprenoid emissions is developed by Guenther et al. (1991, 1993). This approach describes the emission rates using potential emission factors for isoprene $\left(\mathrm{EF}_{I}\right)$ and monoterpenes $\left(\mathrm{EF}_{M}\right)$, and adjusting these potentials by two empirical factors, one describing the response to light intensity and the other to leaf temperature. The correlation between short term fluctuations, light intensity and leaf temperature is widely studied and much work has gone into validating the GUENTHER model under different environmental conditions (e.g. Monson et al., 1994; Petron et al., 2001). The emission factors used in the model are emission rates normalized to a leaf temperature $(T)$ of $30^{\circ} \mathrm{C}$ and quantum flux density $(Q)$ of $1000 \mu \mathrm{mol} \mathrm{m}^{-2} \mathrm{~s}^{-1}$ photosynthetic active radiation (PAR) (Guenther, 1991; Guenther et al., 1993, 1995, 1997). For more information, we refer to the detailed descriptions in these papers.

In the original Guenther model, several coefficients that describe the dependency to light and temperature are fixed parameters. In the MEGAN emission model, these values are dynamic in time and depend on short term $(24 \mathrm{~h})$ and long term ( 10 days) fluctuations in temperature and light intensity (see Guenther et al., 2006). Additionally, the sunlit and shaded parts of the foliage within one canopy layer are parameterised differently, representing their sensitivity to light. These algorithms are applied for all simulations indicated as the MEGAN model, whereas SIM is not used. Other specifications of the MEGAN model are not considered which is possible because we apply the model to an evergreen canopy (in this case no leaf age factor is considered in MEGAN).

NIINEMETS: This model (Niinemets et al., 2002a) for isoprene and monoterpene emissions takes a more processbased approach. It links the emission rates to synthase enzyme activity $\left(S_{S}\right)$ to predict the capacity of isoprenoid synthesis as well as to foliar photosynthetic metabolism via the photosynthetic electron transport rate, $J$, to predict substrate (Niinemets et al., 1999; Niinemets et al., 2002a). The supply of dimethylallyl-pyrophosphate (DMAP) and nicotinamiddinucleotid-phosphate (NADPH), which both depend on the rate of photosynthetic electron transport, are considered to be the main controlling factors.
Emission rates are calculated from the fraction of total electron flow that is used for isoprenoid synthesis, the rate of photosynthetic electron transport, and the cost of isoprenoid synthesis in terms of electrons. Thus, emissions are closely linked to photosynthetic activity of leaves using only one single leaf dependent parameter $\varepsilon$, the fractional allocation of electron transport to synthase activity. Emission rates are given by the equation (Niinemets et al., 1999; Niinemets et al., 2002a):

$E=\varepsilon J_{T} \frac{C_{i}-\Gamma^{*}}{\varsigma\left(4 C_{i}+8 \Gamma^{*}\right)+2\left(C_{i}-\Gamma^{*}\right)(\vartheta-2 \varsigma)}$

where $J_{T}$ is the total rate of photosynthetic electron transport, $C_{i}$ is the internal $\mathrm{CO}_{2}$ concentration, and $\Gamma^{*}$ is the hypothetical $\mathrm{CO}_{2}$ compensation point of photosynthesis that depends on photorespiration (Farquhar and Von Caemmerer, 1982). $\varsigma$ is the carbon cost of specific isoprenoid $\left(6 \mathrm{~mol} \mathrm{~mol}^{-1}\right.$ for isoprene and $12 \mathrm{~mol} \mathrm{~mol}^{-1}$ for monoterpenes) and $\vartheta$ is the NADPH cost of specific isoprenoids $\left(\mathrm{mol} \mathrm{mol}^{-1}\right)$. For monoterpenes, $\vartheta$ is found as a weighted average of the costs of all terpene species emitted. In practice, $\vartheta \cong 28 \mathrm{~mol} \mathrm{~mol}^{-1}$, with small variability because the contribution of oxygenated monoterpenes that may have lower electron cost or reduced monoterpenes that may have higher electron cost is generally small (Niinemets et al., 2002a, 2004). $\varepsilon$, the fractional allocation of electron transport to isoprenoid synthesis, is given by:

$\varepsilon=F_{\mathrm{d}} \frac{S_{S}}{J_{\max }}$

where $S_{\mathrm{s}}$ is the specific activity of isoprenoid synthase (either isoprene or monoterpene synthase) in mol isoprenoid ( $\mathrm{g}$ isoprenoid synthase $)^{-1} \mathrm{~s}^{-1}$ that depends on temperature according to an Arrhenius type equation that has a temperature optimum, and $J_{\max }$ is the light saturated rate of total electron transport that scales with temperature in a similar manner (Niinemets and Tenhunen, 1997). $F_{\mathrm{d}}\left(\mathrm{g} \mathrm{m}^{-2}\right.$ mol electrons mol isoprenoid ${ }^{-1}$ ) is the scaling constant that depends on isoprenoid synthase content $\left(\mathrm{g} \mathrm{m}^{-2}\right)$ and also converts from isoprenoid units to electron transport units (mol isoprenoids mol electrons $^{-1}$ ) (Niinemets et al., 1999, 2002a). Thus, light dependence of isoprenoid emission entirely results from the light effects on photosynthetic electron transport, while temperature dependence is a combined temperature response of isoprenoid synthase and electron transport activities.

BIM2: The BIM2 model (Grote et al., 2006, 2009a) calculates pool changes of isoprene, monoterpene, and a number of precursors representing the methylerythritol-phosphate (MEP) pathway (Rohmer, 1999). The model basically consists of a sequence of first-order Michaelis-Menten equations that depend on instantaneous temperature. Assuming the absence of specific storage structures and neglecting the effect of unspecific storages, the isoprene and monoterpene production is set equal to the emission of these substances. Potential production rates are determined by activities of isoprenoid 
biosynthesis-related enzymes (i.e. isoprene and monoterpene synthases). Primary substrates for the emission model are provided by photosynthesis (Grote et al., 2009a). The emission model uses a fixed internal time step of seven seconds. To mitigate the impact of the different time steps between photosynthetic supply and usage, the supply rate is adjusted to continuously increase or decrease between two consecutively following assimilation rates.

The immediate substrates for isoprenoid formation PEP (phosphoenolpyruvate) and PGA (phosphoglycerate) are assumed to be smaller than the photosynthetic production of triose phosphates $(t p)$, considering exchange equilibrium caused by import and export from the plastids and transformation of triose-phosphate into larger molecules such as starch. The integrated effect is seen as an equilibrium relation to photosynthetic production:

$\mathrm{PGA}=\mathrm{FPGA} \cdot \frac{t p^{2}}{\mathrm{KM}_{t p}}+t p$

$\mathrm{PEP}=(1-\mathrm{FPGA}) \cdot \frac{t p^{2}}{\mathrm{KM}_{t p}+t p}$

$\mathrm{KM}_{t p}$ (Michaelis-Menten constant for triose-phosphate removal) and FPGA (fraction pga of whole available triosephosphates) are empirical determined parameters (units in $\mu \mathrm{mol} \mathrm{L}{ }^{-1}$ ). The relation had been set a priori to 0.375 based on unpublished measurements (Schnitzler, personal communication, 2006). The value is difficult to find in literature for tree species. For crops it has been reported to be between app. 0.5 and 0.9 (e.g. Labate et al 1990; Henkes et al, 2001). However, sensitivity tests show that emission results are hardly sensitive to this ratio (results not presented). $\mathrm{KM}_{t p}$ is estimated to be 100 (see also Grote et al., 2009a).

The concentration of intermediates declines because of use for transformation into higher molecules and transport into other plant compartments. These processes may have numerous environmental dependencies which are not well known and thus are not explicitly considered here. Instead we make the reasonable assumption that the "leaching" of assimilates depends on its concentration and is not directly dependent on production rate. Thus the concentration declines when the "outflow" is larger than the "inflow", provided by photosynthesis. This is the case during conditions where photosynthesis is severely reduced, i.e. during the night or extreme drought. This is simply described by:

$c_{i}^{\prime}=c_{i}-\mathrm{LR}_{i} \cdot t s \cdot c_{i}$

where $t$ denotes the time step $(7 \mathrm{~s})$ and $\mathrm{c}$ is substrate concentration $\left(\mu \mathrm{mol}, \mathrm{L}^{-1}\right)$. Subscript $i$ denote the substrates (PGA, PEP, NADPH, and adenosine-triphosphate [ATP]) as well as the intermediates of the MEP pathway to isoprene and monoterpene production. LR is the loss rate set to the same value for PGA, PEP, and all intermediates. Loss rate has been derived iteratively by fitting BIM 2 to the measured
Monoterpene emission (well watered)

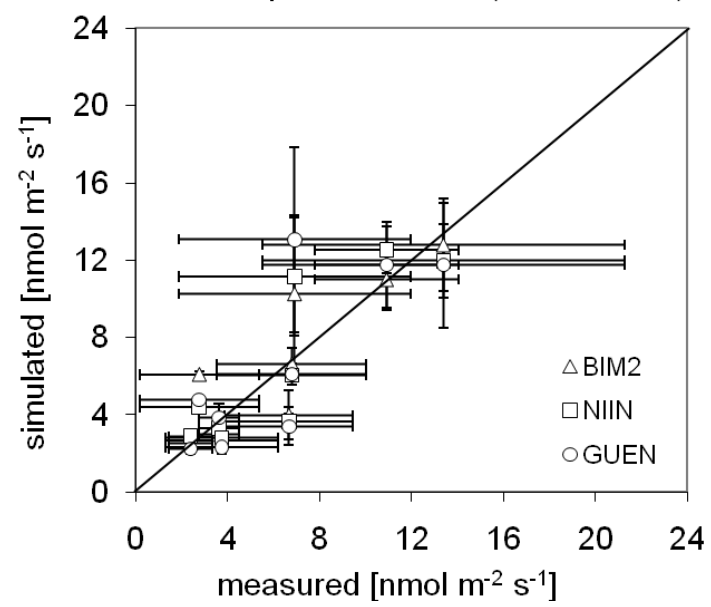

Fig. 2. Simulated and measured leaf scale monoterpene emissions at selected dates in 2006 from sunlit leaves of the well watered Holm oak site. Three models (BIM2, NIINEMETS, GUENTHER) are applied using SIM based seasonality. Each data point represents three leaf-measurements from a separate tree each. The error bars represent the standard deviation of measurements and simulations for three measurements (one per tree) that were carried out per measurement day.

emissions of the well watered plants (Grote et al., 2009a; see Fig. 2). The approximation has been carried out by changing the value in steps of $0.0005 \mu \mathrm{mol} \mu \mathrm{mol}^{-1} \mathrm{~s}^{-1}$ with the aim to obtain concentrations of GDP that are similar to those measured by Nogues et al. (2006) in $Q$. ilex chloroplasts. The resulting value is $0.0035 \mu \mathrm{mol} \mu \mathrm{mol}^{-1} \mathrm{~s}^{-1}$. The loss rates of ATP and NADPH molecules are set 10-fold the value of other molecules to obtain realistic concentrations (Loreto and Sharkey, 1993; Nogues et al., 2006).

\subsubsection{Drought impacts in emission models}

Drought impacts on emissions are realized either directly by reducing the emission process itself, or indirectly by the effect of a reduced photosynthesis. Further indirect impacts, e.g. due to changes in leaf temperature when transpiration is reduced are currently not considered.

The MEGAN model includes a direct effect of limiting soil water availability that has originally been applied for isoprene emissions only (Guenther et al., 2006). In the current approach, both the GUENTHER and MEGAN emission calculations are reduced by drought stress directly in parallel with photosynthesis by applying Eq. 1 . We admit that this direct consideration can hardly be termed "process-based" it serves however as a comparison to the more mechanistic approaches described below. 
The same drought stress formulation determines the response of the NIINEMETS model, but the effect is indirect because not emission itself but the rate of electron transport $\left(J_{T}\right)$ and $\mathrm{Vc}_{\max }$ are reduced by Eq. 1. Since both photosynthetic variables determine the emission capacity, drought stress leads to reduced emissions.

In the BIM2 model, the effect is also indirect because none of the variables used to describe the emission process itself are affected by soil water availability. The impact is solely due to a lack of precursor availability, which is controlled by photosynthetic production and depletion of emission precursors by various processes.

\subsubsection{Emission enzyme activity and emissions potentials}

All other factors being equal, simulated emissions scale linearly with the species specific emission, represented by the emission factor EF. EF has been found to exhibit strong seasonal variation, though this variation has not yet been explained in a process based manner. The SIM model provides a mechanistic description of this seasonal variation, relating the emission potential to temperature and radiation driven enzyme dynamics.

The SIM model is a simple algorithm that derives daily enzyme activity from the previous day's value, an increasing and a decreasing term. The increase is defined by the daily radiation sum $I\left(J \mathrm{~cm}^{-2}\right)$, an Arrhenius term based on daily average temperature, $T\left({ }^{\circ} \mathrm{K}\right)$, and the relative development state of the leaves, pstat, whilst the decrease is a constant fraction of the previous days enzyme activity. Thus the change in enzyme activity for a particular day and canopy layer can be written as:

$\frac{\Delta \mathrm{act}}{d t}=\alpha_{0} \cdot \operatorname{pstat} \cdot I \cdot \operatorname{arrh}-\mu \cdot \mathrm{act}$,

$\operatorname{arrh}=A \cdot e^{\left(\frac{- \text { Eact }}{R \cdot T}\right)}$

where act is the enzyme activity of the previous day $\left(\mu \mathrm{mol} \mathrm{L} \mathrm{s}^{-1} \mathrm{~s}^{-1}\right), R$ the general gas constant $\left(8.3143 \mathrm{~J} \mathrm{~mol}^{-1}\right)$, $\alpha_{0}$ the enzyme formation term $\left(\mathrm{s}^{-1}\right), \mu$ the enzyme decay term $\left(0.175 \mathrm{~s}^{-1}\right)$ (Lehning et al., 2001), $A$ a unitless factor for normalizing the Arrhenius term to 1 at $30^{\circ} \mathrm{C}(660.1 \mathrm{E} 6)$, and $E_{\text {act }}$, the activation energy for a doubling of the reaction velocity $\left(51164.8 \mathrm{~J} \mathrm{~mol}^{-1}\right)$. Emission activity is calculated for each canopy layer separately $\left(\mathrm{nmol} \mathrm{m}^{-2}\right.$ foliage $\mathrm{s}^{-1}$ ). The leaf development term pstat indicates the phenological state of the leaf according to Lehning et al. (2001) and Grote (2007). It increases from 0 to 1 during the period of flushing and decreases with age after senescence has started. The monoterpene synthase formation term, $\alpha_{0}$, is adjusted to measurements taken on site (see Fig. 3).

Enzyme activity is transformed to the emission factor using the specific leaf weight (LSW), which changes linearly with canopy depth from $233 \mathrm{~g} \mathrm{~m}^{-2}$ at the upper canopy

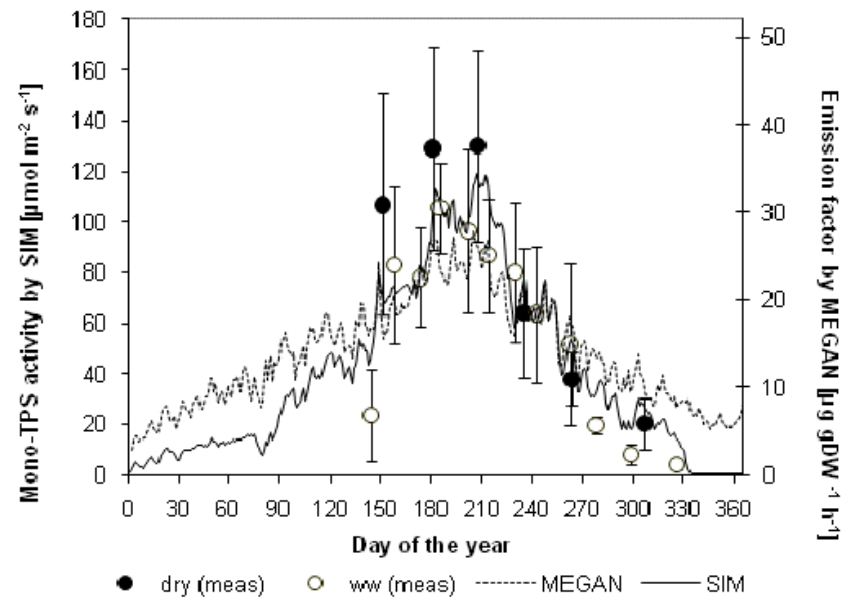

Fig. 3. Seasonal development of monoterpene activity measurements (from both dry and well-watered (ww) trees) and estimated emission factors (for MEGAN and SIM) for the year 2006 (reproduced from Grote et al. 2009a) together with the effective emission factor for the MEGAN model presented on the left y-axis (see text for further information).

boundary to $100 \mathrm{~g} \mathrm{~m}^{-2}$ at the bottom of the canopy (Niinemets et al., 2002b). For the GUENTHER approach, EF $\left(\mu \mathrm{g} \mathrm{g}^{-1}\right.$ dry weight $\left.\mathrm{h}^{-1}\right)$ is given by:

$\mathrm{EF}=\frac{\mathrm{act} \cdot \Theta}{\mathrm{LSW} \cdot F_{\mathrm{SC}}}$

The transformation term $\Theta$ is $120 \times 3.6$, which is the molar mass of carbon atoms within one monoterpene molecule times the transformation from nmol s${ }^{-1}$ into $\mu \mathrm{mol} \mathrm{h}^{-1} . F_{\mathrm{SC}}$ is a factor that accounts for the fact that the enzyme activity reflects a state that is substrate saturated which is never the case and thus has to be reduced to reflect the emission factor. It is adjusted based on the measurements from well watered plants (see below). Similarly, Eq. 7 is also used to derive the basal emission factor for the NIINEMETS approach, $E_{\text {act }}$ $\left(\mu \mathrm{mol} \mathrm{g}^{-1}\right.$ dry weight s${ }^{-1}$ ). The value of $\Theta$ here is 0.01 , corresponding to the unit conversion from nmol to $\mu \mathrm{mol} C \mathrm{C}$ considering 10 carbon atoms in one monoterpene molecule.

For the GUENTHER and NIINEMETS models we calibrated the scaling factor $\left(F_{\mathrm{SC}}\right)$ to the same data (obtained under well watered conditions) in order to approach the 1:1 line for each model separately (see Fig. 2). This resulted in an $F_{\mathrm{SC}}$ value of 5.2 for the GUENTHER and 7.7 for the NIINEMETS model (regression $r^{2}$ values are 0.74 for BIM2 and GUENTHER, and 0.62 for NIINEMETS; standard errors are 2.08, 2.86, and 2.26 for BIM2, GUENTHER and NIINEMETS, respectively).

In order to compare the effect of the seasonality in the three model approaches, simulations are additionally run with a fixed emission factor of $28 \mu \mathrm{gDW}^{-1} \mathrm{~h}^{-1}$ (Seufert et al., 1997) which is in good accordance with the measured maximum factor at the site in Puéchabon reported by 


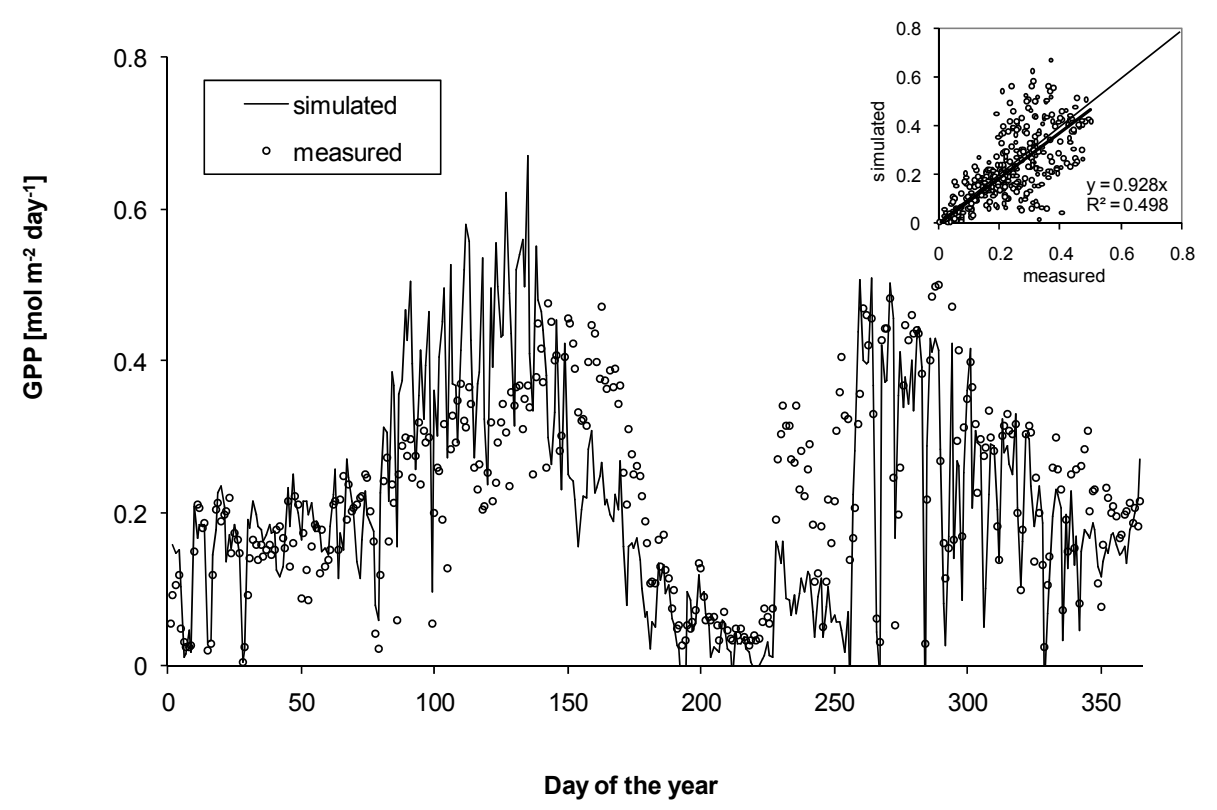

Fig. 4. Simulated and measured gross primary production (GPP) during the year 2006.

Staudt et al. (2002) and Lavoir et al. (2009). The value has been transformed into enzyme activity using the reciprocal of Eq. 7. Additionally, the MEGAN model is run for comparison using the fixed emission factor and the internal modification of variables (see above). The representation of seasonality in the MEGAN model is derived from emission resultcomparisons of MEGAN and GUENTHER models. This is demonstrated in Fig. 3 showing the relation of MEGAN and SIM algorithm output.

\subsubsection{Simulated boundary conditions and other model constraints}

For scaling from leaf to canopy we used assumptions on foliage distribution as outlined in Grote (2007). These are based on measurements of Sala et al. (1994) that show a highly skewed foliage distribution with more than $90 \%$ of the total leaf weight concentrated in the upper $30 \%$ of the canopy. Also, phenological development has been accounted for as described in Grote (2007) considering a variation of leaf area index between 2 and 3.5 with the minimum in spring and the maximum in early summer.

The ECM model calculations of microclimate are discussed in Grote et al. (2009a). They show distinct radiation absorption averaging to $80 \%$ light reduction within the upper half of the canopy but only small variation in temperature (app. $+/-1$ degree between upper and lower canopy layers during typical summer days).

To evaluate simulated photosynthesis at the canopy scale we used data of a continuously measuring flux tower at the Puéchabon site that also provided climatic boundary data (averages 1998-2006 are presented in Allard et al., 2008).
This tower is part of the CarboEurope network (see Baldocchi et al., 2001; Baldocchi, 2003). The correlation between simulations and measurements is reasonably good despite occasional mismatches that are caused by mechanisms not covered in the modelling approach, e.g. there was probably and insect induced foliage loss in spring 2006. The smaller amount of foliage decreased GPP and is a likely reason for an over-estimation of GPP during this time and an over-estimation of drought stress (under-estimation of GPP) during early summer (Fig. 4).

The soil water content calculated daily by the QUERCUS model has been successfully evaluated for the Puéchabon site (Rambal et al., 2003; Grote et al., 2009a) for the period from 1998 to 2006.

\section{Results}

\subsection{Monoterpene emission at leaf scale}

First, we compare the measured leaf scale emissions from the drought stressed Puéchabon site with simulation results from the same time periods (Fig. 5). This is done similarly as described for calibrating the $F_{\mathrm{SC}}$ factor of the NIINEMETS and GUENTHER models, but considering a dynamically calculated drought stress impact (Eq. 1). High $r^{2}$ values (BIM2: 0.82, GUENTHER: 0.69, NIINEMETS: 0.83) and small standard errors (BIM2: 1.65, GUENTHER: 1.65, NIINEMETS: 1.45 ) are obtained for simulating monoterpene emission under these natural conditions (Fig. 5). The slopes of the GUENTHER and NIINEMETS models are less than $1 \%$ different from one. Only the BIM2 model slightly overestimates the emissions under drought stress by $16 \%$. 


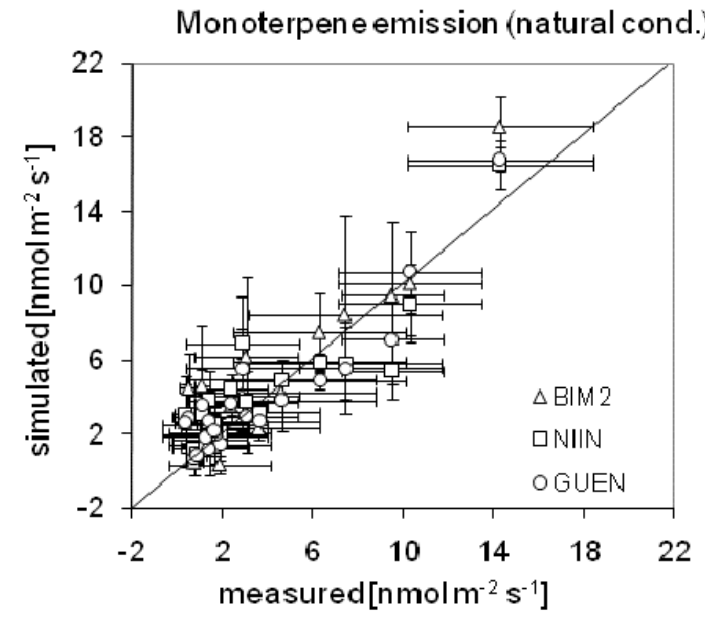

Fig. 5. see Fig. 2 but for drought stressed site and including measurement occasions in 2005 and 2006.

\subsection{Stand scale monoterpene emissions}

\subsubsection{Diurnal effect}

Seasonal and annual model differences originate from the sum of daily emissions which are characterized by their peak amount (usually during midday), the development of emission during the day, and the distribution within the canopy. While it could be shown that the midday emission rate of sunlit leaves is more or less well represented, particularly under well watered conditions (Figs. 2 and 3, Grote et al., 2009), no data are available to evaluate emission from leaves within the canopy or during morning and afternoon periods. Thus, it is important to show why models that are evaluated with the same short-term data may produce different emission sums when longer time periods and the whole canopy are considered.

While differences between models in the sunlit part of the canopy are small (Fig. 6a and b), they are particularly obvious during the drought stress period in the shaded part of the canopy (Fig. 6d). Here, the NIINEMETS model simulates approximately 2-fold higher emissions than the GUENTHER model and 5-fold higher emissions than BIM2. This reflects that the indirect drought response implemented for the NIINEMETS approach is less sensitive to severely limited water supply than the direct response function used for the GUENTHER model. It also shows the particular sensitivity of BIM2 to carbon supply which is decreased by the combined shading and drought impacts.

Other differences are less clear or might cancel out during the day. For example the NIINEMETS model generally simulates a steeper increase of emission in the early hours because only small photosynthetic activities are needed to support monoterpene production. Furthermore, the dependency on photosynthesis in the NIINEMETS and BIM2 approaches enable higher emission rates in the afternoon, particularly in the shaded canopy part, when the decreasing light availability already leads to a steep decrease in emissions simulated by the GUENTHER model (Fig. 6c). It should also be noted that in very occasional cases (hot, no clouds, no drought stress) emission simulation in NIINEMETS and BIM2 (but not in GUENTHER) can be slightly affected by a photosynthetic decline due to stomatal midday depression (days 180, 181).

\subsubsection{Seasonality effect}

The differences in seasonality between the models are demonstrated in Fig. 7 and Table 1. Without drought all models simulate highest emissions in the summer (35-50\% of the annual emission, Fig. 7c). However, summer drought strongly reduces emissions in all models leading to overall similar total emissions in spring and summer despite the temperature differences (Table 1).

The most obvious difference between models is apparent between MEGAN and the models driven by the SIM algorithm: MEGAN produces higher spring emissions due to its higher EF during this period (Fig. 3). However, the model is more sensitive to high temperature periods despite a similar $\mathrm{EF}$, leading to faster in- and decreases.

Comparing the models that use the SIM algorithm, the NIINEMETS model simulates relatively high emissions under low light and temperature conditions while it is less sensitive to environmental changes when these conditions are already good. Thus, emission rates are generally higher than those calculated by GUENTHER and BIM2 in winter, spring and autumn but smaller in summer as long as the drought impact is neglected (Fig. 7a and c). However, as discussed in the next paragraph, the NIINEMETS model (in its presented implementation) is also the least sensitive to drought stress, leading to higher (less decreased) emissions than those calculated with the other two models in summer under natural conditions (Fig. 7b and d).

These different sensitivities between models that can be best observed on a daily time step resolution also result in specific model responses in different years. This has been demonstrated by simulating a period of 10 years (1998 to 2007). First, it is apparent that the NIINEMETS model produces the highest emission under idealized conditions which reflects the former finding of higher spring and autumn emissions (Fig. 8a and b). However, the differences between the models are smaller in years with very warm summers, because the BIM2 and GUENTHER models produce more emissions during this period when no drought is considered. Second, the incorporation of seasonality homogenizes the annual emission results but the smaller differences between years produced by the NIINEMETS model are still apparent (Fig. 8c). The MEGAN model shows a similar yearto-year dynamic than the SIM-based models but produces somewhat higher emissions due to higher spring and autumn emissions (Table 2). Third, seasonal differences between 

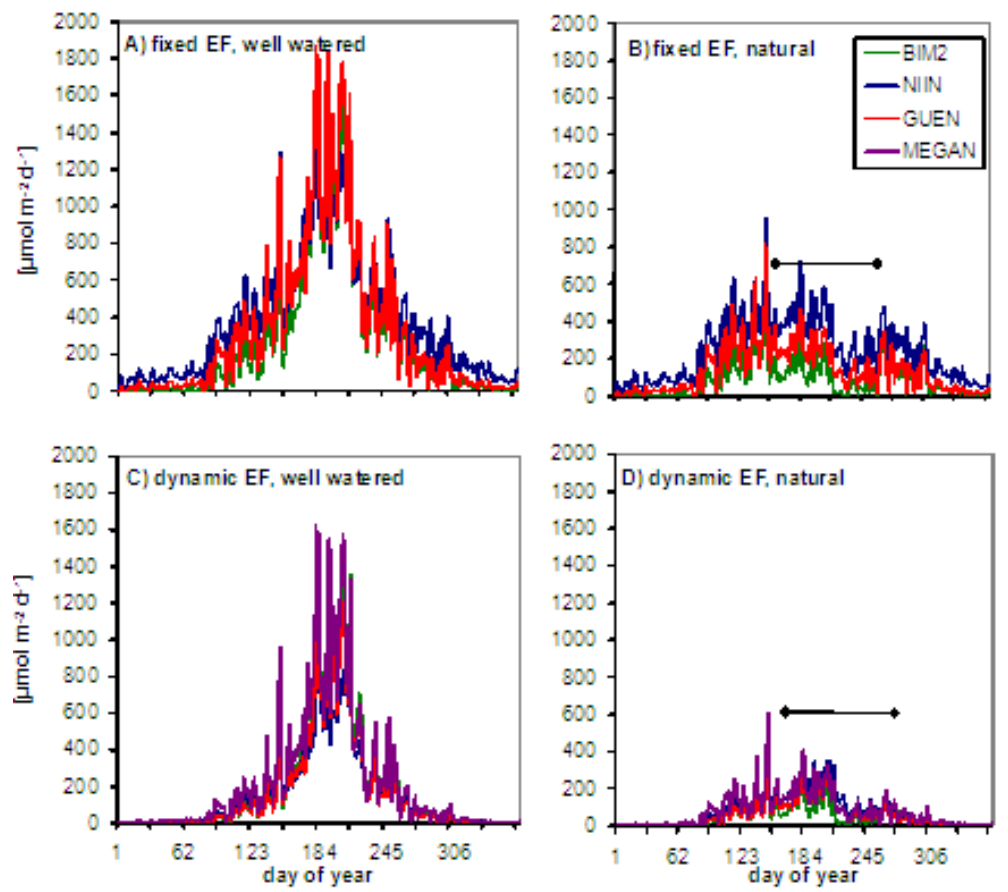

Fig. 6. Diurnal simulated emissions using BIM2, NIINEMETS, and GUENTHER models at selected dates in 2005 (A, C) and 2006 (B, D) for upper and mid canopy locations. Note the different scaling of y-axis.
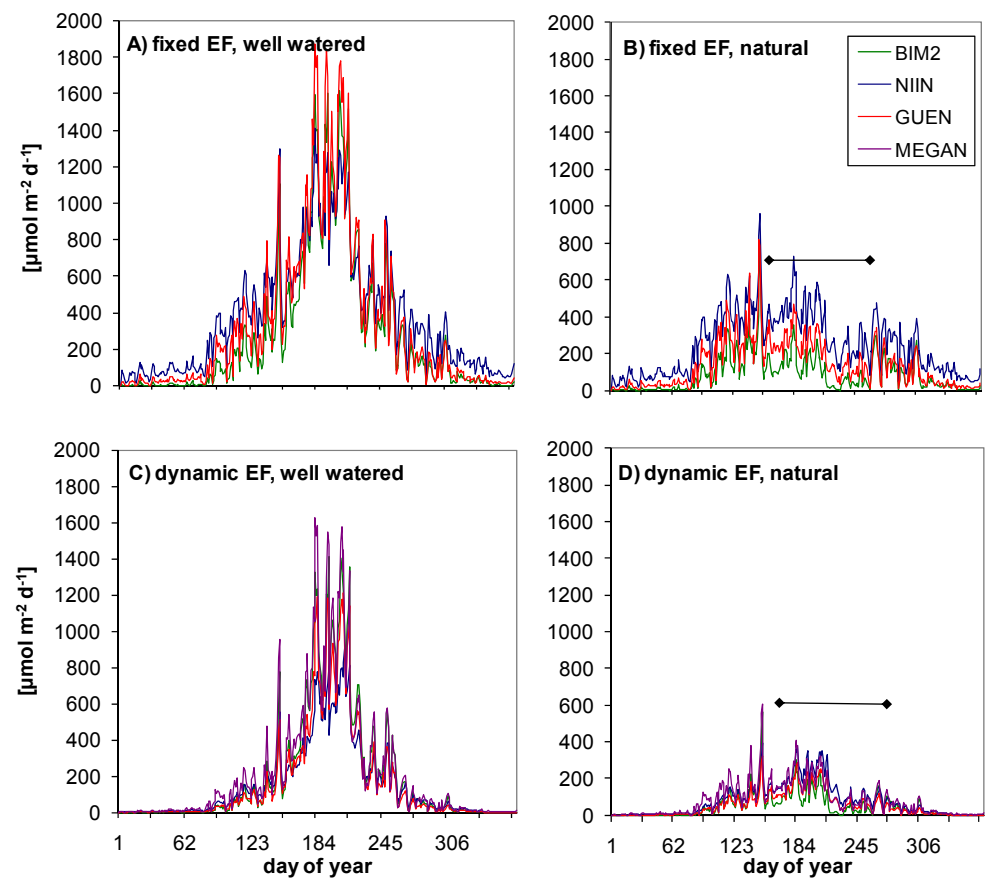

Fig. 7. Simulated daily emissions of the year 2006 based on Puéchabon site information with: (A) a fixed emission potential factor (EF) and no drought effect; (B) a fixed EF and drought effects; (C) a seasonally dynamic EF and no drought effects; (D) a seasonally dynamic EF and drought effects. The seasonally dynamic EF with the NIINEMETS (NIIN), BIM2 and GUENTHER (GUEN) model is estimated using the SIM enzyme dynamics. The MEGAN model explicitly includes an empirically seasonal EF. The period where relative water content fell below $40 \%$ is indicated by the horizontal lines. 
Table 1. Emissions totals $\left(\mathrm{mmol} \mathrm{m}^{-2}\right.$ ) for the periods JFM (January, February, March), AMJ (April, May, June), JAS (July, August, September), and OND (October, November, December) for the four experimental set ups, for each model, at the Puechabon site in 2006. "Average emissions ( $\mathrm{mmol} \mathrm{m}^{-2} \mathrm{yr}^{-1}$ )" refers to the average annual emissions from the three models for a particular experimental setup. EF refers to the basal emissions factor. Values correspond to Fig. 7.

\begin{tabular}{lcccccccc}
\hline & \multicolumn{3}{c}{ Fixed EF, No Drought (Fig. 7a) } & \multicolumn{4}{c}{ Fixed EF, Drought (Fig. 7b) } \\
Period & NIIN & BIM2 & GUEN & Average & NIIN & BIM2 & GUEN & Average \\
\hline JFM & 8.5 & 1.2 & 3.3 & 4.3 & 8.5 & 0.9 & 3.3 & 4.2 \\
AMJ & 48.7 & 32.8 & 42.4 & 41.3 & 37.6 & 15.6 & 24.9 & 26.0 \\
JAS & 64.1 & 59.4 & 69.4 & 64.3 & 29.2 & 9.2 & 16.6 & 18.3 \\
OND & 15.4 & 5.4 & 6.6 & 9.1 & 14.8 & 5.2 & 6.4 & 8.8 \\
Total: & 136.8 & 98.8 & 121.7 & & 90.1 & 31.0 & 51.1 & \\
Average Emissions & & & & & & & & \\
$\left(\right.$ mmol m$^{-2} \mathrm{yr}^{-1}$ ): & & & & 119.1 & & & & 57.4 \\
\hline
\end{tabular}

Table 1. Continued.

\begin{tabular}{|c|c|c|c|c|c|c|c|c|c|c|}
\hline \multirow[b]{2}{*}{ Period } & \multicolumn{5}{|c|}{ Dynamic EF, No Drought (Fig. 7c) } & \multicolumn{5}{|c|}{ Dynamic EF, Drought (Fig. 7d) } \\
\hline & NIIN & BIM2 & GUEN & MEGAN & Average & NIIN & BIM2 & GUEN & MEGAN & Average \\
\hline JFM & 0.6 & 0.1 & 0.3 & 1.1 & 0.5 & 0.6 & 0.1 & 0.3 & 1.1 & 0.5 \\
\hline AMJ & 16.6 & 19.9 & 15.9 & 26.3 & 19.7 & 11.5 & 8.7 & 8.1 & 14.4 & 10.7 \\
\hline JAS & 34.2 & 49.5 & 40.7 & 50.5 & 43.7 & 14.6 & 6.8 & 9.5 & 11.9 & 10.7 \\
\hline OND & 2.0 & 1.7 & 1.0 & 2.4 & 1.8 & 2.0 & 1.6 & 1.0 & 2.3 & 1.7 \\
\hline Total: & 53.5 & 71.2 & 57.9 & 80.2 & & 28.7 & 17.3 & 18.9 & 29.7 & \\
\hline $\begin{array}{l}\text { Average Emissions } \\
\left(\mathrm{mmol} \mathrm{m}^{-2} \mathrm{yr}^{-1}\right) \text { : }\end{array}$ & & & & & 65.7 & & & & & 23.7 \\
\hline
\end{tabular}

different models but also between different years are further reduced by drought stress (Fig. 8d). The negative drought impact on emission compensates (year 2003) or overcompensates (year 2006) the higher emissions due to the warm temperatures in these years.

The correlation of annual total emissions to annual maximum temperatures is better than that to annual mean temperatures. It is also slightly negative to GPP (data not shown) which indicates that temperatures in summer are unfavourable for production even if drought stress is not considered.

\subsubsection{Drought stress effect}

In 2006, in which the most intense drought of all investigated years occurred, photosynthesis as well as simulated emission starts to decline at day 156 when relative water content decreases below a value of $40 \%$ (Fig. $7 \mathrm{~b}$ and d) and recovers only in late summer (day 256). The additional drop in emissions around day 220 is associated with a temperature decline from app. 24 to 18 degrees (daily average). This has not been accompanied with a lot of rainfall so that drought stress is not mitigated. Scaled across the whole canopy, annual emission in 2006 is only between 24 (BIM2) and 45 (NIINEMETS) \% of that calculated for unstressed conditions. On average over the 10 year period, simulated annual emissions are reduced between 28 and 36\% (Table 2). Monoterpene emissions under Mediterranean conditions are more closely correlated to water availability than to primary production or average temperature in all models. The sensitivity, however, is largest in BIM2, leading to particular low simulated emissions in 2006 despite producing otherwise similar results as those of the NIINEMETS model $(-5 \%)$ and moderately smaller values than the GUENTHER model $(-29 \%)$. The MEGAN model produces higher emission estimates than the other models $(+34 \%)$. This reflects the fact that MEGAN contains an empirical measure of seasonality that is not as strong as that represented by the SIM calculations (see Fig. 2) and thus leads to higher emissions particularly outside the dry period in spring and autumn (Fig. 7c and d).

Overall, the application of both a seasonally dynamic emission factor and drought stress dramatically reduces emissions for all models when compared to the original model formulations with fixed potential emission factors and no drought stress. The combined effect of a seasonally dynamic emission factor and drought stress reduces the total emissions budget of the unstressed GUENTHER and NIINEMETS simulations by an average of $74 \%$. 
Table 2. Average and standard deviation (shown in brackets) of annual emissions ( $\mathrm{mmol} \mathrm{m}^{-2} \mathrm{yr}^{-1}$ ) for each model for the four experimental setups at the Puechabon site over the period 1998-2007. "Average emissions ( $\mathrm{mmol} \mathrm{m}^{-2} \mathrm{yr}^{-1}$ )" refers to the average annual emissions from all models for a particular experimental setup. EF refers to the basal emissions factor. Values correspond to Fig. 8.

\begin{tabular}{lcccc}
\hline $\begin{array}{l}\text { Period } \\
1998-2007\end{array}$ & $\begin{array}{c}\text { Fixed EF, } \\
\text { No Drought } \\
\text { (Fig. 8a) }\end{array}$ & $\begin{array}{c}\text { Fixed EF, } \\
\text { Drought } \\
\text { (Fig. 8b) }\end{array}$ & $\begin{array}{c}\text { Dynamic EF, } \\
\text { No Drought } \\
\text { (Fig. 8c) }\end{array}$ & $\begin{array}{c}\text { Dynamic EF, } \\
\text { Drought } \\
\text { (Fig. 8d) }\end{array}$ \\
\hline NIIN & $140.01(8.83)$ & $110.29(11.11)$ & $54.01(10.72)$ & $37.75(4.90)$ \\
BIM2 & $85.83(12.03)$ & $56.45(10.49)$ & $58.13(12.57)$ & $35.77(7.42)$ \\
GUEN & $107.95(13.58)$ & $74.19(9.90)$ & $45.50(12.01)$ & $27.62(4.50)$ \\
MEGAN & - & - & $67.19(12.84)$ & $44.35(6.35)$ \\
$\begin{array}{l}\text { Average Emissions } \\
\left(\mathrm{mmol} \mathrm{m}^{-2} \mathrm{yr}^{-1}\right):\end{array}$ & 111.26 & 80.31 & 56.21 & 36.37 \\
\hline
\end{tabular}
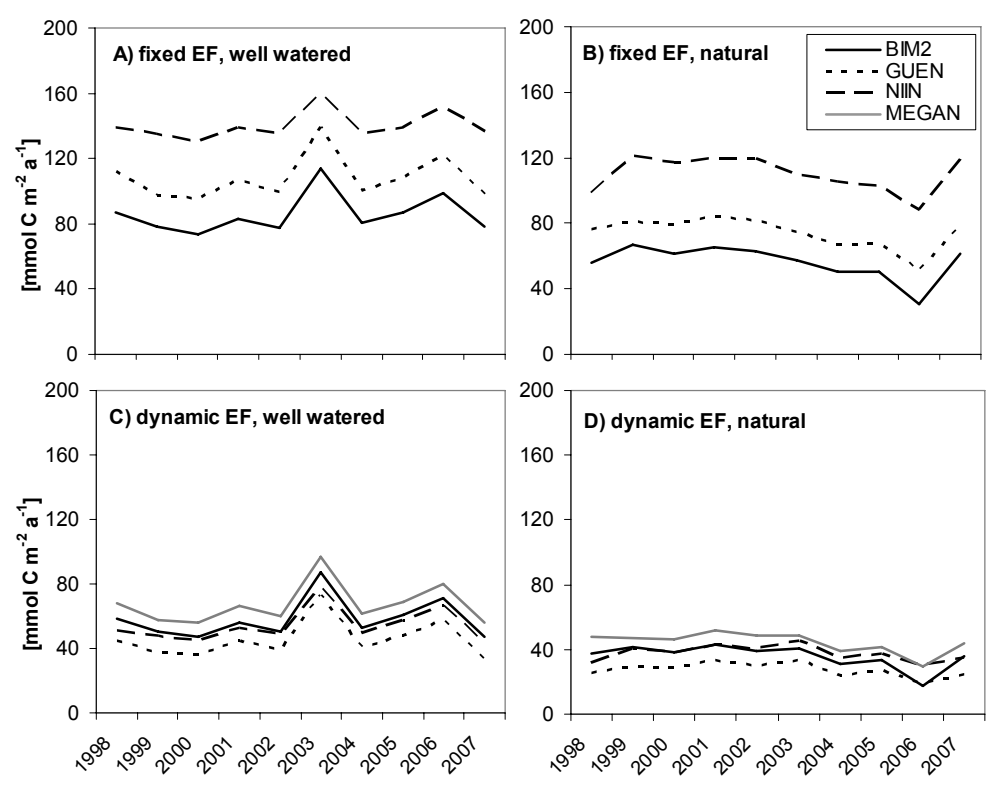

Fig. 8. see Fig. 7 but simulated annual emissions for the period of 1998 to 2007.

\section{Discussion}

\subsection{Seasonal and within canopy variations}

The results demonstrate the potential importance of considering the seasonality of emission dynamics. This corroborates the findings of many authors before (e.g. Monson et al., 1994; Tarvainen et al., 2005; Holzinger et al., 2006; Hakola et al., 2006; Dominguez-Taylor et al., 2007). We have presented a general process-based solution that computes this seasonality from temperature and light conditions which is applicable to at least the most common emission models used today in regional to global applications, be they empirical or more process-based. However, it remains to be investigated to which degree the approach can be applied with regard to species-dependent or plant-functional type related parameters.
The different models show different sensitivity to the temperature and light driven seasonal dynamic impact factor due to the fact that their primary emission algorithms respond differently to these two environmental factors. The NIINEMETS model already has a strong relation to light regime and energy production (see description above and Eq. 3). Thus, with a uniform emission factor, emission can be sustained even in winter because light availability is still sufficient to supply photosynthesis and electron transport at the study site. In the GUENTHER model, the strong and direct response of emissions to both temperature and light results in a stronger seasonality by itself and thus gives a slightly smaller effect of dynamic basal emission. Surprisingly, the smallest effect of an explicitly calculated seasonality is obtained with the BIM2 model although the instantaneous emission response has a similarly strong link to 
temperature development as the GUENTHER model. This is attributed to the fact that emissions additionally depend on photosynthetic substrate supply which is sometimes limiting even under non-stressed conditions, particularly in deeper canopy layers.

Unfortunately, measurement availability is very limited (see Pacifico et al., 2009). It should be considered that past model studies on biogenic emissions have reported to be most sensitive at high temperatures and radiation values (Arneth et al., 2007, Keenan et al., 2009a). This suggests that model differences will probably be larger at more southern locations. Our results therefore represent something of an upper range of model differences due to temperature and light with respect to the time scale included in the study.

The comparison with the MEGAN model shows that seasonality is less expressed than with the SIM approach. Due to limited evaluation data, we cannot judge which model is "better". Also the absolute emission values obtained should be interpreted with care because the leaf-scale emission factor used in this study is determined on sun-lit leaves and is not the same as the "canopy emission factor" used in MEGAN that already takes into account a variation throughout the canopy. It is however assumed that introducing a leaf age factor also to evergreen canopies would bring the MEGAN approach closer to the one applied in SIM. In any case, the finding should encourage further investigations into the matter and indicates that seasonality settings may not easily be transferred between species and regions.

Overall, the application of the SIM algorithm for the calculation of emissions potentials provides a method through which seasonal variation of the basal emission factor (or activity) can be accounted for. Higher temperatures in the future could alter the seasonal cycle of enzyme activity, which may increase the emissions potential, in particular during spring and autumn, where temperature is currently a limiting factor. Increased enzyme activity could lead to increased emissions in the future, a fact that is currently not included with mechanistic detail in any large scale emissions model estimates. The advantage of an activity-based description in comparison to an empirical one is in particular that it can be more easily evaluated. Our example simulations indicate that the SIM mechanism results in smaller and less variable spring and autumn emissions in the Mediterranean area than the standard-MEGAN procedure. This dependence of enzyme activity on the temperature and radiation regime also implies a differentiation of species emission potentials over a climatic gradient, which may explain the reported regional variation in emissions potentials (Guenther et al., 2006) and the generally large variability in reported emission potentials in the literature. The implication of the SIM model may thus provide a mechanistic means of describing regional changes in emissions potentials, but more data is required to reach a conclusive decision.
Due to the dependence of enzyme activity on the temperature and radiation regime, long-term dynamics in dependence on environment also leads to a spatial differentiation of emission factors within the canopy. This corresponds to results from Geron et al. (1994) and Harley et al. (1996) which indicate that the emission capacity varies with canopy depth. In Western Hemlock emission potentials in different canopy heights were significantly different although this was not found in Douglas fir forests (Pressley et al., 2004).

\subsection{Drought stress effect}

Strong and long-lasting drought stress has been observed to significantly reduce BVOC emissions (Bertin and Staudt, 1996; Brüggemann and Schnitzler, 2002; Pegoraro et al, 2004, 2006; Grote et al., 2009a). The quick recovery of the emissions after re-watering suggests that the drought stress related emission decrease is due either to the reduction of synthase activity, or due to reduced substrate availability (Grote and Niinemets, 2008; Grote et al., 2009a). Given the high uncertainty about the role of different processes involved, the resulting magnitude of the reduction of emissions due to drought, and interspecific differences in responses to this stress, modelling emissions during dry periods is still largely a hypothetical exercise (Arneth et al., 2008b; Monson et al., 2007). Here we apply a simple linear reduction function (Eq. 1), but more work is necessary to understand drought stress responses of emissions mechanistically.

No major difference has been observed in the ability of each model to represent the measurements of monoterpene emissions on the leaf scale. The overestimation of $16 \%$ with the BIM2 model indicates that the resource limitation is possibly not the only mechanism responsible for the emission decrease under drought. This is in accordance with the discussion results in Grote et al. (2009a). However, the uncertainties in the measurements are relatively large and need corroboration with additional data, particularly at the stand scale. We thus cannot yet conclude that the models do reproduce the decline in emissions under a natural seasonal drought cycle. The stand scale calculations have shown considerable differences despite very similar results obtained at the leaf scale, which highlights the uncertainty related to temporal and spatial scaling. The BIM2 model shows the largest sensitivity to drought. It is demonstrated that this effect originates from the resource limitation due to drought stress which is increased by the fact that less favourable photosynthetic conditions occur in deeper canopy layers. Despite its relation to photosynthesis the NIINEMETS model has been shown to be the least sensitive to drought stress of the studied models. 


\section{Conclusions}

The presented results that show the effect of seasonality are expected to be generally applicable, for both monoterpenes and isoprene. This is likely to have large ramifications for regional and global emissions estimates (Keenan et al., 2009c), potentially reducing previous emission inventories considerably, in particular in regions characterised by a strong seasonal changes in water availability. The importance for drought exposed systems is due to the fact that dry periods generally converge with times when basal emission activity is high. In such cases the reduction of emission occurs particularly in the potentially most "productive" times whereas in other periods the basal emission potential is limiting. Such regions commonly have a large coverage of isoprenoid-emitting species either due to natural (Kellomäki et al., 2001) or anthropogenic (Vizuete et al., 2002; Lathiere et al., 2006; Geron et al., 2006) reasons (e.g. plantation of crops and fast growing trees to produce bio-energy).

It should however be noted that the estimation of absolute emission amounts is subject to a number of uncertainties related to measurements, model structure, and initialization conditions. With the inclusion of SIM for the calculation of seasonality, we have reduced one of the major sources of differences between emission model estimates, though large differences, particularly in model temperature responses, remain (Arneth et al., 2007; Keenan et al., 2009a). With respect to emission measurements it will be necessary to increase the temporal and spatial density in future studies. It has been shown that variation of annual simulated emissions particularly results from 1) early and late hours of the day, 2) periods in spring and autumn and 3) deeper canopy layers. However, measurements for model evaluation at these times and places are scarce. It has also been demonstrated that the variation between years is considerable which underlines the importance of long-term investigations (Lavoir et al., 2009). Finally, for evaluating the upscaling procedure, stand scale emission measurements are urgently needed.

Due to the lack of evaluation data, we can only argue that the use of SIM is a logical choice under the presumption that the sensitivity of specific emission to temperature and radiation remains the same throughout the canopy. With respect to the different emission models and their drought response, it is currently not possible to conclude which model "is best" since they all represent the data available similarly well. It remains to be shown how leaves within the canopy actually adjust to climate conditions, experience drought stress and respond to this in terms of VOC emission. Model behavior over longer time scales is likely to be similar to that reported here, unless potential climate change is accounted for, in which case model differences have been shown to increase dramatically (Keenan et al., 2009a). Figuring out how strong the temp/light dependencies should be on different timescales should be a focus of research efforts in the future.
We conclude that the consideration of seasonality and drought impacts are highly important elements for isoprenoid emission for many regions, in particular in areas that exhibit seasonal drought stress today or in the future and host isoprenoid emitting plants (e.g. Lathiere et al., 2005; Wang et al., 2007). Our results suggest that many studies involving modelled BVOC emissions (e.g. regional inventories, effects of emissions on tropospheric ozone concentrations and air quality, etc.) may need to be revised to take into account the effect of seasonal cycles on emission estimates.

Acknowledgements. Thanks to the CarboEurope project for the GPP-data and Serge Rambal for helpful comments. A. V. Lavoir was financially supported by the French environmental agency ADEME and the Languedoc-Roussillon regional council; the experimental work was performed within the framework of the European project MIND (EVK2-CT-2002-000158). This work was enabled by support received from the European Science Foundation (ESF) for the activity entitled "Volatile Organic Compounds in the Biosphere-Atmosphere System" (VOCBAS). We further acknowledge the support from the GREENCYCLES Marie-Curie Biogeochemistry and Climate Change Research and Training Network (MRTN-CT-2004-512464) funded by the European Commission's Sixth Framework program.

Edited by: A. Arneth

\section{References}

Allard, V., Ourcival, J. M., Rambal, S., Joffre, R., and Rocheteau, A.: Seasonal and annual variation of carbon exchange in an evergreen Mediterranean forest in southern France, Glob. Change Biol., 14, 714-725, 2008.

Arneth, A., Niinemets, Ü., Pressley, S., Bäck, J., Hari, P., Karl, T., Noe, S., Prentice, I. C., Sera, D., Hickler, T., Wolf, A., and Smith, B.: Process-based estimates of terrestrial ecosystem isoprene emissions: incorporating the effects of a direct $\mathrm{CO} 2$-isoprene interaction, Atmos. Chem. Phys., 7, 31-53, 2007, http://www.atmos-chem-phys.net/7/31/2007/.

Arneth, A., Schurgers, G., Hickler, T., and Miller, P. A.: Effects of species composition, land surface cover, $\mathrm{CO}_{2}$ concentration and climate on isoprene emissions from European forests, Plant Biol., 10, 150-162, 2008.

Arneth, A., Monson, R. K., Schurgers, G., Niinemets, Ü., and Palmer, P. I.: Why are estimates of global terrestrial isoprene emissions so similar (and why is this not so for monoterpenes)?, Atmos. Chem. Phys., 8, 4605-4620, 2008, http://www.atmos-chem-phys.net/8/4605/2008/.

Baldocchi, D., Falge, E., Gu, L. H., Olson, R., Hollinger, D., Running, S., Anthoni, P., Bernhofer, C., Davis, K., Evans, R., Fuentes, J., Goldstein, A., Katul, G., Law, B., Lee, X. H., Mahli, Y., Meyers, T., Munger, W., Oechel, W., Paw-U, K. T., Pilegaard, K., Schmid, H. P., Valentini, R., Verma, S., Vesala, T., Wilson, K., and Wofsy, S.: FLUXNET: A new tool to study the temporal and spatial variability of ecosystem-scale carbon dioxide, water vapor, and energy flux densities, B. Am. Meteorol. Soc., 82, 2415-2434, 2001. 
Baldocchi, D. D.: Assessing the eddy covariance technique for evaluating carbon dioxide exchange rates of ecosystems: past, present and future, Glob. Change Biol., 9, 479-492, 2003.

Ball, J. T., Woodrow, I. E., and Berry, J. A.: A model predicting stomatal conductance and its contribution to the control of photosynthesis under different environmental conditions, in: Progress in photosynthesis research, edited by: Biggins, J., MartinusNijhoff Publishers, Dordrecht, The Netherlands, 221-224, 1987.

Bäck, J., Hari, P., Hakola, H., Juurola, E., and Kulmala, M.: Dynamics of monoterpene emissions in Pinus sylvestris during early spring, Boreal Env. Res., 10, 409-424, 2005.

Beniston, M., Stephenson, D. B., Christensen, O. B., Ferro, C. A. T., Frei, C., Goyette, S., Halsnaes, K., Holt, T., Jylhä, K., Koffi, B., Palutikof, J., Schöll, R., Semmler, T., and Woth, K.: Future extreme events in European climate: an exploration of regional climate model projections, Climatic Change, 81, 71-95, 2007.

Bertin, N. and Staudt, M.: Effect of water stress on monoterpene emissions from young potted holm oak (Quercus ilex L.) trees. Oecologia, 107, 456-462, 1996.

Brilli, F., Barta, C., Fortunati, A., Lerdau, M., Loreto, F., and Centritto, M.: Response of isoprene emission and carbon metabolism to drought in white poplar (Populus alba) saplings, New Phytol., 175, 244-254, 2007.

Brüggemann, N. and Schnitzler, J.-P.: Comparison of isoprene emission, intercellular isoprene concentration and photosynthetic performance in water-limited oak (Quercus pubescens Willd. and Quercus robur L.) saplings, Plant Biol., 4, 456-463, 2002.

Ciccioli, P., Fabozzi, C., Brancaleoni, E., Cecinato, A., Frattoni, M., Loreto, F., Kesselmeier, J., Schäfer, L., Bode, K., Torres, L., and Fugit, J.-L.: Use of the isoprene algorithm for predicting the monoterpene emission from the Mediterranean holm oak Quercus ilex L.: Performance and limits of this approach, J. Geophys. Res., 102, 23319-23328, 1997.

Dominguez-Taylor, P., Ruiz-Suarez, L. G., Rosas-Perez, I., Hernandez-Solis, J. M., and Steinbrecher, R.: Monoterpene and isoprene emissions from typical tree species in forests around Mexico City, Atmos. Environ., 41, 2780-2790, 2007.

Farquhar, G. D. and von Caemmerer, S.: Modelling of photosynthetic response to environmental conditions, in: Physiological plant ecology. II, Water relations and carbon assimilation, edited by: Lange, O. L., Nobel, P. S., Osmond, C. B., and Ziegler, H., Springer, Berlin, 549-587, 1982.

Fiore, A. M., Horowitz, L. W., Purves, D. W., Levy II, H., Evans, M. J., Wang, Y., Li, Q., and Yantosca, R. M.: Evaluating the contribution of changes in isoprene emissions to surface ozone trends over the eastern United States, J. Geophys. Res., 110, doi:10.1029/2004JD005485, 2005.

Fischbach, R. J., Zimmer, I., Steinbrecher, R., Pfichner, A., and Schnitzler, J.-P.: Monoterpene synthase activities in leaves of Picea abies (L.) Karst. and Quercus ilex L., Phytochemistry, 54, 257-265, 2000.

Fischbach, R. J., Staudt, M., Zimmer, I., Rambal, S., and Schnitzler, J.-P.: Seasonal pattern of monoterpene synthase activities in leaves of the evergreen tree Quercus ilex, Physiol. Plant., 114, 354-360, 2002.

Fuentes, J. D. and Wang, D.: On the seasonality of isoprene emissions from a mixed temperate forest, Ecol. Appl., 9, 1118-1131, 1999.
Fuentes, J. D., Lerdau, M., Atkinson, R., Baldocchi, D., Bottenheim, J. W., Ciccioli, P., Lamb, B., Geron, C., Gu, L., Guenther, A., Sharkey, T. D., and Stockwell, W.: Biogenic hydrocarbons in the atmosphere boundary layer: a review., B. Am. Meteorol. Soc., 81, 1537-1575, 2000.

Funk, J. L., Jones, C. G., Gray, D. W., Throop, H. L., Hyatt, L. A., and Lerdau, M. T.: Variation in isoprene emission from Quercus rubra: Sources, causes, and consequences for estimating fluxes, J. Geophys. Res., 110, doi:10.1029/2004JD005229, 2005.

Gelencscer, A., May, B., Simpson, D., Scanchez-Ochoa, A., Kasper-Giebl, A., Puxbaum, H., Caseiro, A., Pio, C., and Legrand, M.: Source apportionment of PM2.5 organic aerosol over Europe: Primary/secondary, natural/anthropogenic, and fossil/biogenic origin, J. Geophys. Res., 112, D23S04, doi:10.1029/2006JD008094, 2007.

Geron, C. D., Guenther, A. B., and Pierce, T. E.: An improved model for estimating volatile organic compound emissions from forests in the eastern United States, J. Geophys. Res., 99, 12773 12791, 1994.

Geron, C. D., Nie, D., Arnts, R. R., Sharkey, T. D., Singsaas, E. L., Vanderveer, P. J., Guenther, A., Sickles II, J. E., and Kleindienst, T. E.: Biogenic isoprene emission: Model evaluation in a southeastern United States bottomland deciduous forest, J. Geophys Res., 102, 18903-18916, 1997.

Geron, C., Guenther, A., Sharkey, T., and Arnts, R. R.: Temporal variability in basal isoprene emission factor, Tree Physiol., 20, 799-805, 2000.

Geron, C., Owen, S., Guenther, A., Greenberg, J., Rasmussen, R., Bai, J. H., Li, Q.-J., and Baker, B.: Volatile organic compounds from vegetation in southern Yunnan Province, China: Emission rates and some potential regional implications, Atmos. Environ., 40, 1759-1773, 2006.

Giorgi, F.: Climate change hot-spots, Geophys. Res. Lett., 33, L08707, doi:10.1029/2006GL025734, 2006.

Giorgi, F., Bi, X., and Pal, J.: Mean, interannual variability and trends in a regional climate change experiment over Europe. II: climate change scenarios (2071-2100), Clim. Dynam., 23, 839_ 858, 2004.

Gitay H., Brown S., Easterling W., and Jallow B.: Ecosystems and their goods and services, in: Climate Change 2001: Impacts, Adaptation and Vulnerability, edited by: McCarthy, J. J., Canziani, O. F., Leary, N. A., Dokken, D. J., and White, K. S., Cambridge University Press, Cambridge, UK, 236-341, 2001.

Grote, R., Mayrhofer, S., Fischbach, R. J., Steinbrecher, R., Staudt, M., and Schnitzler, J.-P.: Process-based modelling of isoprenoid emissions from evergreen leaves of Quercus ilex (L.), Atmos. Environ., 40, 152-165, 2006.

Grote, R.: Sensitivity of volatile monoterpene emission to changes in canopy structure - A model based exercise with a processbased emission model, New Phytol., 173, 550-561, 2007.

Grote, R. and Niinemets, Ü.: Modeling volatile isoprenoid emissions - A story with split ends, Plant Biol., 10, 8-28, 2008.

Grote, R., Lavoir, A. V., Rambal, S., Staudt, M., Zimmer, I., and Schnitzler, J.-P.: Modelling the drought impact on monoterpene fluxes from an evergreen Mediterranean forest canopy, Oecologia, 160, 213-222, 2009a.

Grote, R., Lehmann, E., Brümmer, C., Brüggemann, N., Szarzynski, J., and Kunstmann, H.: Modelling and observation of biosphere-atmosphere interactions in natural savannah in Burk- 
ina Faso, West Africa, Phys. Chem. Earth, 34, 251-260, 2009b.

Guenther, A., Zimmerman, P., Harley, P., Monson, R., and Fall, R.: Isoprene and monoterpene emission rate variability: Model evaluations and sensitivity analysis, J. Geophys. Res., 98, 1260912617, 1993.

Guenther, A., Karl, T., Harley, P., Wiedinmyer, C., Palmer, P. I. and Geron, C.: Estimates of global terrestrial isoprene emissions using MEGAN (Model of Emissions of Gases and Aerosols from Nature). Atmos.Chem.Phys., 6, 3181-3210, 2006.

Guenther, A., Hewitt, C. N., Erickson, D., Fall, R., Geron, C., Graedel, T., Harley, P., Klinger, L., Lerdau, M., McKay, W. A., Pierce, T., Scholes, B., Steinbrecher, R., Tallamraju, R., Taylor, J., and Zimmerman, P.: A global model of natural volatile organic compound emissions, J. Geophys. Res., 100, 8873-8892, 1995.

Guenther, A.: Seasonal and spatial variations in natural volatile organic compound emissions, Ecol. Appl., 7, 34-45, 1997.

Guenther, A. B., Monson, R. K., and Fall, R.: Isoprene and monoterpene emission rate variability: Observations with $\mathrm{Eu}$ calyptus and emission rate algorithm development, J. Geophys. Res., 96, 10799-10808, 1991.

Hakola, H., Tarvainen, V., Bäck, J., Ranta, H., Bonn, B., Rinne, J., and Kulmala, M.: Seasonal variation of mono- and sesquiterpene emission rates of Scots pine, Biogeosciences, 3, 93-101, 2006, http://www.biogeosciences.net/3/93/2006/.

Hansen, U. and Seufert, G.: Terpenoid emission from Citrus sinensis (L.) OSBECK under drought stress, Phys. Chem. Earth (Part B), 24, 681-687, 1999.

Hanson, D. T. and Sharkey, T. D.: Rate of acclimation of the capacity for isoprene emission in response to light and temperature, Plant Cell Environ., 24, 937-946, 2001.

Harley, P., Guenther, A., and Zimmerman, P.: Effects of light, temperature and canopy position on net photosynthesis and isoprene emission from sweetgum (Liquidambar styraciflua) leaves, Tree Physiol., 16, 25-32, 1996.

He, C., Murray, F., and Lyons, T.: Seasonal variations in monoterpene emissions from Eucalyptus species, Chemosphere - Global Change Science, 2, 65-76, 2000.

Henkes, S., Sonnewald, U., Badur, R., Flachmann, R., and Stitt, M.: A Small Decrease of Plastid Transketolase Activity in Antisense Tobacco Transformants Has Dramatic Effects on Photosynthesis and Phenylpropanoid Metabolism, Plant Cell, 13, 535-551, 2001.

Holst, J., Grote, R., Offermann, C., Ferrio, J. P., Gessler, A., Mayer, H., and Rennenberg, H.: Water fluxes within beech stands in complex terrain, Int. J. Biometeorol, 54, 23-36, doi:10.1007/s00484-009-0248-x, 2009.

Holzinger, R., Lee, A., McKay, M., and Goldstein, A. H.: Seasonal variability of monoterpene emission factors for a ponderosa pine plantation in California, Atmos. Chem. Phys., 6, 1267-1274, 2006,

http://www.atmos-chem-phys.net/6/1267/2006/.

Kanakidou, M., Seinfeld, J. H., Pandis, S. N., Barnes, I., Dentener, F. J., Facchini, M. C., Van Dingenen, R., Ervens, B., Nenes, A., Nielsen, C. J., Swietlicki, E., Putaud, J. P., Balkanski, Y., Fuzzi, S., Horth, J., Moortgat, G. K., Winterhalter, R., Myhre, C. E. L., Tsigaridis, K., Vignati, E., Stephanou, E. G., and Wilson, J.: Organic aerosol and global climate modelling: a review, Atmos. Chem. Phys., 5, 1053-1123, 2005, http://www.atmos-chem-phys.net/5/1053/2005/.

Keenan, T., Niinemets, Ü., Sabate, S., Gracia, C., and Peñuelas, J.: Process based inventory of isoprenoid emissions from European forests: model comparisons, current knowledge and uncertainties, Atmos. Chem. Phys., 9, 4053-4076, 2009,

http://www.atmos-chem-phys.net/9/4053/2009/.

Keenan, T., Garca, R., Friend, A. D., Zaehle, S., Gracia, C., and Sabate, S.: Improved understanding of drought controls on seasonal variation in Mediterranean forest canopy $\mathrm{CO}_{2}$ and water fluxes through combined in situ measurements and ecosystem modelling, Biogeosciences, 6, 1423-1444, 2009, http://www.biogeosciences.net/6/1423/2009/.

Keenan, T., Niinemets, Ü., Sabate, S., Gracia, C., and Peñuelas, J.: Seasonality of monoterpene emission potentials in Quercus ilex and Pinus pinea: Implications for regional VOC emissions modeling, J. Geophys. Res., 114, D22202, doi:10.1029/2009JD011904, 2009c.

Kellomäki, S., Rouvinen, I., Peltola, H., Strandman, H., and Steinbrecher, R.: Impact of global warming on the tree species composition of boreal forests in Finland and effects on emissions of isoprenoids, Glob. Change Biol., 7, 531-544, 2001.

Labate, C. A., Adcock, M. D., and Leegood, R. C.: Effects of temperature on the regulation of photosynthetic carbon assimilation in leaves of maize and barley, Planta, 181, 547-554, 1990.

Lathiere, J., Hauglustaine, D. A., and De Noblet-Ducoudre, N.: Past and future changes in biogenic volatile organic compound emissions simulated with a global dynamic vegetation model, Geophys. Res. Lett., 32, L20818, doi:10.1029/2005GL024164, 2005.

Lathière, J., Hauglustaine, D. A., Friend, A. D., De NobletDucoudré, N., Viovy, N., and Folberth, G. A.: Impact of climate variability and land use changes on global biogenic volatile organic compound emissions, Atmos. Chem. Phys., 6, 2129-2146, 2006, http://www.atmos-chem-phys.net/6/2129/2006/.

Lavoir, A.-V., Staudt, M., Schnitzler, J. P., Landais, D., Massol, F., Rocheteau, A., Rodriguez, R., Zimmer, I., and Rambal, S.: Drought reduced monoterpene emissions from the evergreen Mediterranean oak Quercus ilex: results from a throughfall displacement experiment, Biogeosciences, 6, 1167-1180, 2009, http://www.biogeosciences.net/6/1167/2009/.

Lehning, A., Zimmer, I., Steinbrecher, R., Brüggemann, N., and Schnitzler, J. P.: Isoprene synthase activity and its relation to isoprene emission in Quercus robur L. leaves, Plant Cell Environ., 22, 495-504, 1999.

Lehning, A., Zimmer, W., Zimmer, I., and Schnitzler, J.-P.: Modeling of annual variations of oak (Quercus robur L.) isoprene synthase activity to predict isoprene emission rates, J. Geophys. Res., 106, 3157-3166, 2001.

Li, C., Frolking, S., and Frolking, T. A.: A model of nitrous oxide evolution from soil driven by rainfall events: 1 . Model structure and sensitivity, J. Geophys. Res., 97, 9759-9776, 1992.

Long, S. P.: Modification of the response of photosynthetic productivity to rising temperature by atmospheric $\mathrm{CO}_{2}$ concentrations: Has its importance been underestimated?, Plant Cell Environ., 14, 729-739, 1991.

Loreto, F. and Sharkey, T. D.: On the relationship between isoprene emission and photosynthetic metabolites under different environmental conditions, Planta, 189, 420-424, 1993.

Loreto, F., Fischbach, R. J., Schnitzler, J. P., Ciccioli, P., Brancale- 
oni, E., Calfapietra, C., and Seufert, G.: Monoterpene emission and monoterpene synthase activities in the Mediterranean evergreen oak Quercus ilex $\mathrm{L}$. grown at elevated $\mathrm{CO}_{2}$ concentrations, Glob. Change Biol., 7, 709-717, 2001.

Mayrhofer, S., Teuber, M., Zimmer, I., Louis, S., Fischbach, R. J., and Schnitzler, J.-P.: Diurnal and seasonal variation of isoprene biosynthesis-related genes in grey poplar leaves, Plant Physiol., 139, 474-484, 2005.

Menzel, A., Sparks, T. H., Estrella, N., Koch, E., Aasa, A., Ahas, R., Alm-Kübler, K., Bissolli, P., Braslavska, O., Briede, A., Chmielewski, F. M., Crepinsek, Z., Curnel, Y., Dahl, A., Defila, C., Donnelly, A., Filella, Y., Jatczak, K., Mage, F., Mestre, A., Nordli, O., Peñuelas, J., Pirinen, P., Remisova, V., Scheifinger, H., Striz, M., Susnik, A., Van Vliet, A. J. H., Wielgolaski, F.-E., Zach, S., and Zust, A.: European phenological response to climate change matches the warming pattern, Glob. Change Biol., 12, 1969-1976, 2006.

Misson, L., Baldocchi, D. D., Black, T. A., Blanken, P. D., Brunet, Y., Curiel Yuste, J., Dorsey, J. R., Falk, M., Granier, A., Irvine, M. R., Jarosz, N., Lamaud, E., Launiainen, S., Law, B. E., Longdoz, B., Loustau, D., McKay, M., Paw, U., Vesala, T., Vickers, D., Wilson, K. B., and Goldstein, A. H.: Partitioning forest carbon fluxes with overstory and understory eddy-covariance measurements: A synthesis based on FLUXNET data, Agric. Forest Meteorol., 144, 14-31, 2007.

Monson, R. K., Harley, P. C., Litvak, M. E., Wildermuth, M., Guenther, A. B., Zimmerman, P. R., and Fall, R.: Environmental and developmental controls over the seasonal pattern of isoprene emission from aspen leaves, Oecologia, 99, 260-270, 1994.

Monson, R. K., Trahan, N., Rosenstiel, T. N., Veres, P., Moore, D., Wilkinson, M., Norby, R. J., Volder, A., Tjoelker, M. G., Briske, D. D., Karnosky, D. F., and Fall, R.: Isoprene emission from terrestrial ecosystems in response to global change: minding the gap between models and observations, Phil. Trans. R. Soc. Lond. A, 365, 1677-1695, 2007.

Müller, J.-F., Stavrakou, T., Wallens, S., De Smedt, I., Van Roozendael, M., Potosnak, M. J., Rinne, J., Munger, B., Goldstein, A., and Guenther, A. B.: Global isoprene emissions estimated using MEGAN, ECMWF analyses and a detailed canopy environment model, Atmos. Chem. Phys., 8, 1329-1341, 2008, http://www.atmos-chem-phys.net/8/1329/2008/.

Niinemets, Ü. and Tenhunen, J. D.: A model separating leaf structural and physiological effects on carbon gain along light gradients for the shade-tolerant species Acer saccharum, Plant Cell Environ., 20, 845-866, 1997.

Niinemets, Ü., Oja, V., and Kull, O.: Shape of leaf photosynthetic electron transport versus temperature response curve is not constant along canopy light gradients in temperate deciduous trees, Plant Cell Environ., 22, 1497-1513, 1999.

Niinemets, Ü., Seufert, G., Steinbrecher, R., and Tenhunen, J. D.: A model coupling foliar monoterpene emissions to leaf photosynthetic characteristics in Mediterranean evergreen Quercus species, New Phytol., 153, 257-273, 2002a.

Niinemets, Ü., Hauff, K., Bertin, N., Tenhunen, J. D., Steinbrecher, R., and Seufert, G.: Monoterpene emissions in relation to foliar photosynthetic and structural variables in Mediterranean evergreen Quercus species, New Phytol., 153, 243-256, 2002 b.

Niinemets, Ü., Loreto, F., and Reichstein, M.: Physiological and physicochemical controls on foliar volatile organic compound emissions, Trends Plant Sci., 9, 180-186, 2004.

Nogues, I., Brilli, F., and Loreto, F.: Dimethylallyl diphosphate and geranyl diphosphate pools of plant species characterized by different isoprenoid emissions, Plant Physiol., 141, 721-730, 2006.

Olofsson, M., Ek-Olausson, B., Jensen, N. O., Langer, S., and Ljungstrom, E.: The flux of isoprene from a willow coppice plantation and the effect on local air quality, Atmos. Environ., 39, 2061-2070, 2005.

Pacifico, F., Harrison, S. P., Jones, C. D., and Sitch, S.: Isoprene emission and climate, Atmos. Environ., 43(39), 61216135, doi:10.1016/j.atmosenv.2009.09.002, 2009.

Pegoraro, E., Rey, A., Greenberg, J., Harley, P., Grace, J., Mahli, Y., and Guenther, A.: Effect of drought on isoprene emission rates from leaves of Quercus virginiana Mill., Atmos. Environ., 38, 6149-6156, 2004.

Petron, G., Harley, P., Greenberg, J., and Guenther, A.: Seasonal temperature variations influence isoprene emissions, Geophys. Res. Lett., 28, 1707-1710, 2001.

Pierce, T., Geron, C., Bender, L., Dennis, R., Tonnesen, G., and Guenther, A.: Influence of increased isoprene emissions on regional ozone modeling, J. Geophys. Res.-Atmos., 103, 2561125629, 1998.

Pio, C. A., Silva, P. A., Cerqueira, M. A., and Nunes, T. V.: Diurnal and seasonal emissions of volatile organic compounds from cork oak (Quercus suber) trees, Atmos. Environ., 39, 1817-1827, 2005.

Plaza, J., Nunez, L., Pujadas, M., Perrez-Pastor, R., Bermejo, V., Garcia-Alonso, S., and Elvira, S.: Field monoterpene emission of Mediterranean oak (Quercus ilex) in the central Iberian Peninsula measured by enclosure and micrometeorological techniques: Observation of drought stress effect, J. Geophys. Res., 110, D03303, doi:10.1029/2004JD005168, 2005.

Possell, M., Hewitt, C. N., and Beerling, D. J.: The effects of glacial atmospheric $\mathrm{CO}_{2}$ concentrations and climate on isoprene emissions by vascular plants, Glob. Change Biol., 11, 60-69, 2005.

Pressley, S., Lamb, B., Westberg, H., Guenther, A., Chen, J., and Allwine, E.: Monoterpene emissions from a Pacific Northwest Old-Growth Forest and impact on regional biogenic VOC emission estimates, Atmos. Environ., 38, 3089-3098, 2004.

Priestley, C. H. B. and Taylor, R. J.: On the assessment of surface heat flux and evaporation using large-scale parameters, Mon. Weather Rev., 100, 81-92, 1972.

Rambal, S.: The differential role of mechanisms for drought resistances in a Mediterranean evergreen shrub: a simulation approach, Plant Cell Environ., 16, 35-44, 1993.

Rambal, S., Ourcival, J.-M., Joffre, R., Mouillot, F., Nouvellon, Y., Reichstein, M., and Rocheteau, A.: Drought controls over conductance and assimilation of a Mediterranean evergreen ecosystem: scaling from leaf to canopy, Glob. Change Biol., 9, 18131824, 2003.

Rohmer, M.: The discovery of a mevalonate-independent pathway for isoprenoid biosynthesis in bacteria, algae and higher plants, Nat. Prod. Rep., 16, 565-574, 1999.

Sala, A., Sabaté, S., Gracia, C. and Tenhunen, J. D.: Canopy structure within a Quercus ilex forested watershed: variations due to location, phenological development, and water availability, Trees, 8, 254-261, 1994.

Schaab, G., Steinbrecher, R., and Lacaze, B.: Influence of seasonality, canopy light extinction, and terrain on potential isoprenoid 
emission from a Mediterranean-type ecosystem in France, J. Geophys. Res.-Atmos., 108, 1-14, 2003.

Seufert, G., Bartzis, J., Bomboi, T., Ciccioli, P., Cieslik, S., Dlugi, R., Foster, P., Hewitt, C. N., Kesselmeier, J., Kotzias, D., Lenz, R., Manes, F., Paster, R. P., Steinbrecher, R., Torres, L., Valentini, R., and Versino, B.: An overview of the Castelporziano experiments, Atmos. Environ., 31, 5-17, 1997.

Spitters, C. J. T., Toussaint, H. A. J. M., and Goudriaan, J.: Separating the diffuse and direct component of global radiation and its implications for modeling canopy photosynthesis. Part I., Components of incoming radiation, Agric. Forest Meteorol., 38, 217229, 1986.

Staudt, M., Bertin, N., Frenzel, B., and Seufert, G.: Seasonal variation in amount and composition of monoterpenes emitted by young Pinus pinea trees - Implications for emission modeling, J. Atmos. Chem., 35, 77-99, 2000.

Staudt, M., Joffre, R., and Rambal, S.: How growth conditions affect the capacity of Quercus ilex leaves to emit monoterpenes, New Phytol., 158, 61-73, 2003.

Staudt, M., Ennajah, A., Mouillot, F., and Joffre, R.: Do volatile organic compound emissions of Tunisian cork oak populations originating from contrasting climatic conditions differ in their responses to summer drought?, Can. J. For. Res., 38, 2965-2975, 2008.

Staudt, M., Rambal, S., Joffre, R., and Kesselmeier, J.: Impact of drought on seasonal monoterpene emissions from Quercus ilex in southern France, J. Geophys. Res., 107, 4602-4608, 2002.
Szidat, S., Jenk, T. M., Synal, H. A., Kalberer, M., Wacker, L., Hajdas, I., Kasper-Giebl, A., and Baltensperger, U.: Contributions of fossil fuel, biomass-burning, and biogenic emissions to carbonaceous aerosols in Zurich as traced by C-14, J. Geophys. Res., 111(D7), D07206, doi:10.1029/2005JD006590, 2006.

Tarvainen, V., Hakola, H., Hellén, H., Bäck, J., Hari, P., and Kulmala, M.: Temperature and light dependence of the VOC emissions of Scots pine, Atmos. Chem. Phys., 5, 989-998, 2005, http://www.atmos-chem-phys.net/5/989/2005/.

Tie, X., Li, G., Ying, Z., Guenther, A., and Madronich, S.: Biogenic emissions of isoprenoids and $\mathrm{NO}$ in China and comparison to anthropogenic emissions, Sci. Total Environ., 371, 238-251, 2006.

Vizuete, W., Junquera, V., McDonald-Buller, E., McGaughey, G., Yarwood, G., and Allen, D.: Effects of temperature and land use on predictions of biogenic emissions in Eastern Texas, USA, Atmos. Environ., 36, 3321-3337, 2002.

Walther, G.-R., Post, E., Convey, P., Menzel, A., Parmesan, C., Beebee, T. J. C., Fromentine, J.-M., Hoegh-Guldberg, O., and Bairlein, F.: Ecological responses to recent climate change, Nature, 416, 389-395, 2002.

Wang, S. and Davidson, A.: Impact of climate variations on surface albedo of a temperate grassland, Agric. Forest Meteorol., 142, 133-142, 2007. 